University of Windsor

Scholarship at UWindsor

$10-2019$

\title{
The Full Picture: Preliminary Examinations at the International Criminal Court
}

Sara Wharton

University of Windsor, Faculty of Law

Rosemary Grey

Sydney Law School \& Sydney Southeast Asia Centre, The University of Sydney

Follow this and additional works at: https://scholar.uwindsor.ca/lawpub

Part of the Criminal Law Commons, and the International Law Commons

\section{Recommended Citation}

Wharton, Sara and Grey, Rosemary. (2019). The Full Picture: Preliminary Examinations at the International Criminal Court. Canadian Yearbook of International Law, 56, 1-57.

https://scholar.uwindsor.ca/lawpub/108

This Article is brought to you for free and open access by the Faculty of Law at Scholarship at UWindsor. It has been accepted for inclusion in Law Publications by an authorized administrator of Scholarship at UWindsor. For more information, please contact scholarship@uwindsor.ca. 


\section{The Full Picture: Preliminary Examinations at the International Criminal Court Sara Wharton and Rosemary Grey}

\section{INTRODUCTION}

The Office of the Prosecutor (OTP) at the International Criminal Court (ICC) has described preliminary examinations as "one of the Office's three core activities," alongside investigating and prosecuting crimes within the jurisdiction of the Court. ${ }^{1}$ In the fifteen years since the first prosecutor took office, the Office has opened 27 preliminary examinations, the most recent concerning crimes allegedly committed in the Philippines and Venezuela, as announced on 8 February 2018, ${ }^{2}$ and the alleged deportation of Rohingya people from Myanmar to Bangladesh, announced on 18 September 2018. ${ }^{3}$ In the ICC's early years, there was little public information about this important aspect of the OTP's work. As a result, the significance of preliminary examinations was not widely appreciated outside the Court, and there was little research on this pre-investigative process. ${ }^{4}$ However, this began to change with increased public reporting on preliminary examinations by the OTP, and greater attention to this topic in media reporting on the Court. In fact, these days the mere decision to open a preliminary examination can have a significant impact, including prompting two states (Burundi and the Philippines) to withdraw from the ICC's founding treaty, the 1998 Rome Statute. ${ }^{5}$ Additionally,

\footnotetext{
${ }^{1}$ ICC-OTP, OTP Strategic Plan: 2016-2018, 16 November 2015, online: <https://www.icc-cpi.int/iccdocs/otp/enotp_strategic_plan_2016-2018.pdf> (accessed 16 August 2018) at para. 55 [2016-2018 Strategic Plan].

2 ICC-OTP, "Statement of the Prosecutor of the International Criminal Court, Mrs Fatou Bensouda, on opening Preliminary Examinations into the situation in the Philippines and Venezuela", 8 February 2018, online: <https://www.icc-cpi.int/Pages/item.aspx?name=180208-otp-stat> (accessed 31 August 2018) [Statement of OTP on opening Philippines and Venezuela II Preliminary Examinations].

${ }^{3}$ ICC-OTP, "Fatou Bensouda, on opening a Preliminary Examination concerning the alleged deportation of the Rohingya people from Myanmar to Bangladesh", 18 September 2018, online: <https://www.icccpi.int/Pages/item.aspx?name $=180918$-ot-stat-Rohingya $>$ (accessed 7 November 2018) [Statement of OTP on opening Rohingya/Myanmar Preliminary Examination].

${ }^{4}$ For some earlier work, see Héctor Olásolo, "The prosecutor of the ICC before the initiation of investigations: A quasijudicial or a political body?” (2003) 3:2 Intl Crim L Rev 87; Ignaz Stegmiller, The Pre-Investigative Stage of the ICC: Criteria for Situation Selection (Berlin: Duncker \& Humblot, 2011).

5 "Burundi", ICC Website, online: <https://www.icc-cpi.int/burundi> (accessed 4 August 2008); ICC, "ICC Statement on The Philippines' notice of withdrawal: State participation in Rome Statute system essential to international rule of
} 
preliminary examinations have, in recent years, been identified as an important area of research ${ }^{6}$ leading to a recent thought-provoking collection of essays on preliminary examinations ${ }^{7}$ together with useful analyses of discrete parts of the preliminary examination puzzle, including the process for opening a preliminary examination, ${ }^{8}$ the purpose of preliminary examinations, ${ }^{9}$ their duration, ${ }^{10}$ how the principles of complementarity, "positive complementarity"12, and gravity ${ }^{13}$ function at this stage of proceedings, and the limited scope for judicial review in preliminary examinations. ${ }^{14}$

Missing from this literature is a comprehensive picture of the practice of the ICC Prosecutor in relation to all preliminary examinations opened thus far. Filling that gap, this article provides an indepth analysis of all preliminary examinations up until the 2018 annual preliminary examinations report. It reviews legal decisions made at the preliminary examination stage, and identifies patterns in

law”, 20 March 2018, ICC-CPI-20180320-PR1371. See also Rosemary Grey and Sara Wharton, "Lifting the Curtain: Opening a Preliminary Examination at the International Criminal Court” (2018) 16:3 J Intl Criminal Justice 593.

${ }^{6}$ For example, the Grotius Centre for International Legal Studies held an expert seminar on preliminary examinations on 29 September 2015. See Grotius Centre for International Legal Studies, "Preliminary Examinations and Legacy/Sustainable Exit: Reviewing Policies and Practices”, online: <http://postconflictjustice.com/wpcontent/uploads/2015/10/Report-Preliminary-Examination-and-Legacy_Sustainable-Exit_Reviewing-Policies-andPractices.pdf $>$ (accessed 25 March 2018) [“Grotius Centre Report”].

${ }^{7}$ Morten Bergsmo and Carsten Stahn, eds, Quality Control in Preliminary Examinations (Vol. 1 \& 2) (Brussels: Torkel Opsahl Academic EPublisher, 2018).

${ }^{8}$ Grey and Wharton, supra note 5.

${ }^{9}$ E.g. Carsten Stahn, "Damned If You Do, Damned If You Don't, Challenges and Critiques of Preliminary Examinations at the ICC” (2017) 15 J Intl Criminal Justice 413; Mark Kersten, "Casting a Larger Shadow': Premeditated Madness, the International Criminal Court, and Preliminary Examinations" in Morten Bergsmo and Carsten Stahn, eds, Quality Control in Preliminary Examinations (Vol. 2) Chapter 33 (Brussels: Torkel Opsahl Academic EPublisher, 2018) 655 .

${ }^{10}$ E.g. Anni Pues, "Towards the 'Golden Hour'? A Critical Exploration of the Length of Preliminary Examinations" (2017) 15:3 J Intl Criminal Justice 435; Stahn, supra note 9, at 428-29; Mark Kersten, "How Long can the ICC Keep Palestine and Israel in Purgatory?” (29 February 2016), Justice in Conflict (blog), online:

<https://justiceinconflict.org/2016/02/29/how-long-can-the-icc-keep-palestine-and-israel-in-purgatory/> (accessed 25 March 2018).

${ }^{11}$ E.g. Louise Chappell, Rosemary Grey and Emily Waller, “The Gender Justice Shadow of Complementarity: Lessons from the International Criminal Court's Preliminary Examinations in Guinea and Colombia” (2013) 7:2 I J Transitional Justice 455.

12 Justine Tillier, “The ICC Prosecutor and Positive Complementarity: Strengthening the Rule of Law?” (2013) 13:3 Intl Crim L Rev 507 at 511-552; Amrita Kapur, "The Value of International-National Interactions and Norm Interpretations in Catalysing National Prosecutions of Sexual Violence” (2016) 6(1) Oñati Socio-Legal Series.

${ }^{13}$ E.g. Alette Smeulers, Maartje Weerdesteijn and Barbara Hola, "The Selection of Situations by the ICC: An Empirically Based Evaluation of the OTP's Performance" (2015) 15:1 Intl Crim L Rev 1; Margaret M. deGuzman, "Gravity and the Legitimacy of the International Criminal Court" (2009) 32:5 Fordham Intl L J 1400 at 1409-1415; Stahn, supra note 9, at 426-27.

${ }^{14}$ E.g. Stahn, supra note 9, at 430-32. 
the triggers, outcomes, duration, frequency, and geographic representation of all preliminary examinations under the leadership of its two different prosecutors, Luis Moreno-Ocampo (June 2003 - June 2012) and Fatou Bensouda (June 2012 - present). This in-depth analysis shows that, despite not having full investigatory powers during preliminary examinations, the OTP is very active during this phase. It interacts with a wide range of domestic and international actors, including state parties, non-party states, the United Nations (UN) Security Council, and members of civil society. It also makes decisions on legal issues that go to the heart of the ICC's work, including questions about the ICC's jurisdiction and about the definition of crimes which are yet to be interpreted by judges of the Court. As such, preliminary examinations form a major part of the OTP's work, demanding significant time and resources, and cannot be overlooked when evaluating the Court.

Paying close attention to what goes on during the preliminary examination stage is therefore crucial to understanding what the OTP does, and sheds light on why certain crimes are later investigated and prosecuted by the ICC, while others are not. It provides insight into who seeks to "use" the court by triggering preliminary examinations and their success in doing so, as well as whether or not that usage has changed over the lifespan of the court as it has faced challenges and criticisms. Finally, understanding the full picture of the OTP's preliminary examination practice is critical to understanding and nuancing many debates surrounding the legitimacy of the Court including its independence, impartiality, efficiency, and transparency. ${ }^{15}$ The currency date of the 2018 Preliminary Examination Report (specifically, 30 November 2018) provides a useful marker for a study of the OTP's preliminary examination practice thus far. ${ }^{16}$ Of course, there are and always will be new developments to this practice as the OTP continues its work. However, this study demonstrate trends

\footnotetext{
15 As Stahn notes, preliminary examinations "have a key role to play in relation to the legitimacy and perception of justice", ibid at 415.

${ }^{16}$ ICC-OTP, Report on Preliminary Examination Activities 2018, 5 December 2018, online: <https://www.icccpi.int/itemsDocuments/181205-rep-otp-PE-ENG.pdf> (accessed 5 December 2018) at para. 17 [2018 PE Report].
} 
over more than fifteen years of OTP practice, and will provide a point of comparison for future research in the area, perhaps in another fifteen years.

The article begins by introducing the legal regime governing preliminary examinations, and outlines relevant policies published by the OTP. It then presents our study of the OTP's preliminary examination practice to date, beginning with the method, and then presenting and discussing our key findings.

\section{WHAT IS A PRELIMINARY EXAMINATION?}

Put simply, a preliminary examination is the "pre-investigative phase" of the OTP's work. ${ }^{17}$ More specifically, it is the initial filtering process that the ICC prosecutor undertakes in order to decide whether or not there is a "reasonable basis to proceed to an investigation" by considering the factors listed in article 53(1) of the Rome Statute, namely: whether the information available provides a reasonable basis to believe that a crime within the ICC's jurisdiction has been or is being committed; whether the potential cases would be admissible before the ICC; and whether an investigation would not serve the interests of justice. ${ }^{18}$

The question of precisely what activities constitute a preliminary examination, as opposed to a "pre-preliminary examination" process, is the subject of some debate. This debate arose recently in the ICC proceedings regarding a possible investigation into crimes allegedly committed in Myanmar and Bangladesh. In its September 2018 decision on that matter, Pre-Trial Chamber I held that: "the preliminary examination is the pre-investigative assessment through which the Prosecutor analyses the seriousness of the information 'received' or 'made available' to her against the factors set out in article

${ }^{17}$ ICC-OTP, Annex to the Paper on some policy issues before the Office of the Prosecutor': Referrals and Communications, online: $<$ https://www.icc-cpi.int/NR/rdonlyres/278614ED-A8CA-4835-B91D-

DB7FA7639E02/143706/policy_annex_final_210404.pdf> (accessed 16 August 2018) at 3-4 [Annex to 2003 Policy Paper].

${ }^{18}$ ICC Rules of Procedure and Evidence at Rule 48 [ICC RPE]. 
53(1)(a)-(c) of the Statute." ${ }^{\prime 19}$ Applying that interpretation, it held that the Prosecutor's actions in receiving information on alleged crimes against the Rohingya people, and considering "at least in part" that information against the factors described in article 53(1)(a)-(c), "do not precede a preliminary examination, but are part of it' ${ }^{20}$ By contrast, the Prosecutor's view was that those activities occurred in a pre-preliminary examination stage that the OTP describes as "Phase 1" of its four stage "filtering process" during which it conducts its "initial assessment of all information on alleged crimes received under article 15". ${ }^{21}$ Thus, the OTP does not consider the "formal commencement of a preliminary examination" to occur until Phase 2 of this process. ${ }^{22}$

This divergence in views is unsurprising, given the lack of clarity on this stage of proceedings in the Rome Statute. Despite being a core component of the OTP's work, the term "preliminary examination" appears just once in the Statute. Specifically, article 15(6) refers to "the preliminary examination referred to in paragraphs 1 and 2" which state, respectively, that the Prosecutor may initiate investigations proprio motu (on his or her own motion) on the basis of information on crimes within the ICC's jurisdiction, and that he or she may also seek out information from any "reliable sources". ${ }^{23}$ If the Prosecutor seeks to proceed to an investigation proprio motu, he or she must apply to the Pre-Trial Chamber for authorization to open an investigation. ${ }^{24}$ On the other hand, if the prosecutor received a referral from either the UN Security Council or a state party, the Prosecutor may proceed from a preliminary examination straight to an investigation if he or she decides that the article 53(1) criteria are satisfied.

\footnotetext{
${ }^{19}$ ICC, Request Under Regulation 46(3) of the Regulations of the Court, "Decision on the 'Prosecution's Request for a Ruling on Jurisdiction under Article 19(3) of the Statute”, p-T. Ch. I, 6 September 2018, ICC-RoC46(3)-01/18-37 at para. 82.

${ }^{20}$ Ibid (emphasis added).

212018 PE Report, supra n 16, at para. 15; ICC, Request Under Regulation 46(3) of the Regulations of the Court, "Prosecution Response to Observations by Intervening Participants", OTP, 11 July 2018, ICC-RoC46(3)-01/18-33, at fn 10. See also Grey and Wharton supra note 5.

222018 PE Report, supra note 16.

${ }^{23}$ Rome Statute of the International Criminal Court, 17 July 1997, 2187 UNTS 3 [Rome Statute].

${ }^{24}$ Ibid, Articles 15(3) and (4).
} 
If the Prosecutor reaches the conclusion that the article 53(1) criteria have not been met, he or she must notify the information provider, be it an individual, non-governmental organization (NGO), state, or the Security Council, of that conclusions and the supporting reasons. ${ }^{25}$ If the situation was referred by a state party or the Security Council, that referring entity can ask the Pre-Trial Chamber to review the Prosecutor's decision not to proceed. ${ }^{26}$ However, the power of judicial review here is very limited, despite the fact that the Prosecutor will inevitably have to make many important legal and factual determinations at this stage. The referring entity is not entitled to judicial review as a right, ${ }^{27}$ and the Chamber cannot quash the Prosecutor's decision even if it is deemed unreasonable or errant; at most, it can ask the Prosecutor to "reconsider". ${ }^{28}$ On the other hand, if the conclusion not to proceed to an investigation is made on the basis of article 53(1)(c), namely that prosecution(s) would not be "in the interests of justice", the OTP must inform the Pre-Trial Chamber. ${ }^{29}$ This provides the only basis upon which the Pre-Trial Chamber can review the Prosecutor's decision on its own initiative and must confirm that decision for it to be effective. ${ }^{30}$ Finally, article 15 of the Rome Statute explicitly states that a decision to close a preliminary examination "shall not preclude the Prosecutor from considering further information submitted to him or her regarding the same situation in light of new facts or evidence." 31 Thus, the Prosecutor may re-open a preliminary examination at any time in light of new evidence, which has occurred only once thus far.

Given the limited statutory guidance on the conduct of preliminary examinations, it is helpful to consider relevant policies produced by the OTP which, while not binding, are key to understanding the Office's approach to this area of its practice. First, in a September 2003 document, the OTP made

\footnotetext{
25 Ibid, Article 15(6); ICC RPE, supra note 18, Rules 105 and 49.

${ }^{26}$ Rome Statute, supra note 23, Article 53(3)(a).

${ }^{27}$ Ibid ("At the request of the State making a referral under article 14 or the Security Council under article 13, paragraph

(b), the Pre-Trial Chamber may review a decision of the Prosecutor ...") [emphasis added].

${ }^{28}$ Ibid.

${ }^{29}$ See also ICC, Regulations of the Office of the Prosecutor, ICC-BD/05-01-09, 23 April 2009, Regulation 31.

${ }^{30}$ Rome Statute, supra note 23, Article 53(3)(b).

31 Ibid, Article 15(6).
} 
clear that a preliminary examination is always required before the Prosecutor can proceed to an investigation, even if the situation was referred by a state party or the UN Security Council (even though the term "preliminary examination" only appears in the statutory provision dealing with investigation initiated by the Prosecutor proprio motu $).{ }^{32}$

In November 2013, the OTP published a final Policy Paper on Preliminary Examinations, ${ }^{33}$ which was based on an early October 2010 draft. $^{34}$ This 2013 Policy Paper outlines the principles that guide the OTP in its preliminary examinations, namely: independence, impartiality and objectivity. ${ }^{35}$ It also articulates the four-phase process that the Office applies in conducting preliminary examinations, namely: examining article 15 communications from states, civil society and individuals to rule out those that fall "manifestly outside the jurisdiction of the Court" (Phase 1); determining whether or not the alleged crimes appear to fall within the jurisdiction of the ICC (Phase 2); determining whether or not the potential cases would be admissible to the Court (Phase 3); and determining whether or not an investigation would be against the "interests of justice" (Phase 4). ${ }^{36}$ The Policy Paper states that those criteria of "jurisdiction", "admissibility", and the "interests of justice" are assessed in the same manner regardless of the trigger for the preliminary examination. ${ }^{37}$ It also states that the OTP will publish regular reports on its preliminary examination activities, in line with its commitment to transparency at the preliminary examination stage. ${ }^{38}$

\footnotetext{
32 See Annex to 2003 Policy Paper, supra note 17, at 3-4.

33 ICC-OTP, Policy Paper on Preliminary Examinations, November 2013, online: <https:/ /www.icccpi.int/iccdocs/otp/otp-policy_paper_preliminary_examinations_2013-eng.pdf> (accessed 4 August 2018) at para. 77 [PE Policy Paper].

34 ICC-OTP, Policy Paper on Preliminary Examinations: DRAFT, 4 October 2010, The Hague, online: <https://www.icccpi.int/nr/rdonlyres/9ff1eaa1-41c4-4a30-a202-

174b18da923c/282515/otp_draftpolicypaperonpreliminaryexaminations04101.pdf> (accessed 17 August 2018).

35 PE Policy Paper, supra note 33, at paras 25-33.

36 Ibid at paras $77-83$.

${ }^{37}$ Ibid at para. 35.

38 Ibid at paras 94-9.
} 
In addition to that specific policy paper, a number of other OTP policies are also relevant to the preliminary examination process. For example, in September 2007, the OTP produced its Policy Paper on the Interests of Justice which guides the OTP's consideration of this criteria under article 53(1)(c) of the Rome Statute. ${ }^{39}$ As well, the OTP's June 2014 Policy Paper on Sexual and Gender-Based Crimes ${ }^{40}$ and 2016 Policy on Children ${ }^{41}$ inform the conduct and focus of preliminary examinations. This is apparent, for example, in the OTP's statement that it will pay "particular attention to the commission of sexual and gender-based crimes at all stages of its work", including at the preliminary examination phase. ${ }^{42}$ Furthermore, these policy papers provide guidance as to how the relevant criteria should be analyzed, such as the assessment of the genuineness of national proceedings for the purposes of determining admissibility, ${ }^{43}$ the gravity threshold (noting that sexual and gender-based crimes as well as crimes against children are particularly grave),${ }^{44}$ and the interests of justice criterion. ${ }^{45}$

Finally, a number of the strategic goals delineated in the OTP's most recent Strategic Plan are relevant to preliminary examinations, such as Strategic Goal 3 which includes: developing the contribution that preliminary examinations can make to future investigations and prosecutions, promoting national proceedings, continuing its policy of increased transparency for preliminary examinations, enhancing the deterrent effect of preliminary examinations, and timely completion of preliminary examinations. ${ }^{46}$

\footnotetext{
39 ICC-OTP, Policy Paper on the Interests of Justice, 2007, online: <https://www.icc-cpi.int/NR/rdonlyres/772C95C9-F54D4321-BF09-73422BB23528/143640/ICCOTPInterestsOfJustice.pdf > (accessed 17 August 2018). 40 ICC-OTP, Policy Paper on Sexual and Gender-Based Crimes, June 2014, online: <https:/ /www.icccpi.int/iccdocs/otp/otp-policy-paper-on-sexual-and-gender-based-crimes--june-2014.pdf> (accessed 17 August 2018), paras 38-47 [Policy Paper on Sexual and Gender-Based Crimes]. 
That, in brief, is the framework governing preliminary examinations. But how has this framework been applied in the 15 years since the first Prosecutor took office at the ICC? That question is the starting point for our study, the method and findings of which are detailed below.

\section{RESEARCH METHOD}

For this study, we conducted a review of all preliminary examinations opened by the ICC Prosecutor up until the 2018 Preliminary Examination Report (specifically, 30 November 2018). As noted above, the question of when a preliminary examination begins - and therefore, how many preliminary examination have been "opened" - is the subject of debate. However, for this study, we have counted only those situations in which the OTP has acknowledged that a "preliminary examination" - in name or in substance - has occurred. ${ }^{47}$ This brings the total to twenty-seven preliminary examinations, namely: Afghanistan; Bangladesh/Myanmar; Burundi; Central African Republic I (CAR I); Central African Republic II (CAR II); Colombia; Registered Vessels of Comoros, Greece and Cambodia (Comoros); Côte d'Ivoire; Darfur, Sudan (Darfur); the Democratic Republic of the Congo (DRC); Gabonese Republic (Gabon); Georgia; Guinea; Honduras; Iraq/UK; Kenya; Libya; Mali; Nigeria; Palestine I; Palestine II; Republic of Korea (South Korea); Republic of the Philippines (the Philippines); Uganda; Ukraine; Venezuela I; and Venezuela II.

The study is based on a review of information made publically available by the OTP, most notably the detailed reports on preliminary examination activities published from 2011 onwards. ${ }^{48}$ In

\footnotetext{
${ }^{47}$ The OTP did not use the term "preliminary examination" in its early practice. However, it referred in substance to this pre-investigative process.

48 Starting in 2011 the OTP began publishing annual reports on its preliminary examination activities. Additionally, in relation to certain situations it released what it calls "Article 53(1) Reports" upon the conclusion of certain preliminary examinations. ICC-OTP, Situation in Mali: Article 53(1) Report, 16 January 2013, online: <https:/ /www.icccpi.int/itemsDocuments/SASMaliArticle53_1PublicReportENG16Jan2013.pdf > (accessed 16 August 2018) [Mali Article 53(1) Report]; ICC-OTP, Situation in the Central African Republic II: Article 53(1) Report, 24 September 2014, online: <https://www.icc-cpi.int/iccdocs/otp/art_53_1_report_car_ii_24sep14.pdf> (accessed 16 August 2018) [CAR II Article 53(1) Report]; ICC-OTP, Situation on Registered Vessels of Comoros, Greece and Cambodia: Article 53(1) Report, 6 November 2014, online: <https://www.icc-cpi.int/iccdocs/otp/otp-com-article_53(1)-report-06nov2014eng.pdf>
} 
earlier years, the Office did not routinely publish such information. Nonetheless, some information about earlier preliminary examinations can be found in the annual reports of the Court to the Assembly of States Parties (ASP), annual ICC reports to the UN General Assembly, and some public statements of the OTP.

After collating this information, we then classified all preliminary examinations according to relevant criteria. The first of these was the relevant geographic region(s), including the region(s) where the alleged crimes were committed (state of territorial jurisdiction) as well as the region(s) that the alleged perpetrators were from if known (state of nationality jurisdiction). For this purpose, we used the UN General Assembly regional categories. ${ }^{49}$

The second criterion was the "trigger" for the preliminary examination using four categories: State Party referral; UN Security Council referral; a decision made by the Prosecutor proprio motu on the basis of an article 12(3) declaration; or a decision made by the Prosecutor proprio motu without an article 12(3) declaration. We distinguished between these two types of proprio motu situations because

(accessed 16 August 2018) [Comoros Article 53(1) Report]. The OTP also published what it calls "Article 5 Reports" detailing its conclusion in relations to issues of subject-matter jurisdiction. ICC-OTP, Situation in Nigeria: Article 5 Report, 5 August 2013, online: <https://www.icc-cpi.int/iccdocs/PIDS/docs/SAS\%20-\%20NGA\%20-

$\% 20$ Public $\% 20$ version $\% 20$ Article $\% 205 \% 20$ Report $\% 20-\% 2005 \% 20$ August $\% 202013$.PDF> (accessed 16 August 2018) [Nigeria Article 5 Report]; ICC-OTP, Situation in the Republic of Korea: Article 5 Report, June 2014, online:

$<$ https://www.icc-cpi.int/iccdocs/otp/sas-kor-article-5-public-report-eng-05jun2014.pdf> (accessed 16 August 2018) [South Korea Article 5 Report]; ICC-OTP, Situation in Honduras: Article 5 Report, October 2015, online:

$<$ https://www.icc-cpi.int/iccdocs/otp/SAS-HON-Article_5_Report-Oct2015-ENG.PDF> (accessed 16 August 2018) [Honduras Article 5 Report]; ICC-OTP, Situation in the Gabonese Republic: Article 5 Report, 21 September 2018, online $<$ https://www.icc-cpi.int/itemsDocuments/180921-otp-rep-gabon_ENG.pdf> (accessed 7 November 2018) [Gabon Article 5 Report]. Finally, the OTP published an "Interim Report" in relation to the situation in Colombia in November 2012. ICC-OTP, Situation in Colombia: Interim Report, November 2012, online: <https://www.icccpi.int/nr/rdonlyres/3d3055bd-16e2-4c83-ba85-

35bcfd2a7922/285102/otpcolombiapublicinterimreportnovember2012.pdf > (accessed 16 August 2018) [Colombia Interim Report]. As well, the OTP prepares detailed requests for authorization to proceed to an investigation for situations opened proprio motu if the Prosecutor determines that the article 53(1) criteria are fulfilled which contain considerable information about the preliminary examination that led to that decision.

49 "United Nations Regional Groups of Member States", Department for General Assembly and Conference Management Website, online: <http://www.un.org/depts/DGACM/RegionalGroups.shtml> (accessed 16 August 2018). Palestine is not included in any regional grouping at the UN as of yet but is listed as an Asia-Pacific state by the ICC's ASP and was categorized as such. "Asia-Pacific States", ICC Website, online: < https://asp.icc-

cpi.int/en_menus/asp/states\%20parties/asian\%20states/Pages/asian\%20states.aspx> (accessed 16 August 2018). 
the OTP has a policy of treating these situations differently, ${ }^{50}$ and because experience shows that the relevant state(s) are likely to react differently depending on whether or not they invited the ICC to intervene. Where there were two triggers for the same preliminary examination, we classified the situation according to the first one temporally ${ }^{51}$ because the second has no effect in terms of triggering a preliminary examination (but can have a subsequent legal effect, namely, if the second trigger is a referral from a State Party or the Security Council, the Prosecutor can proceed to an investigation without judicial authorization).

The third criterion was the outcome of the preliminary examination, with the options being: decision not to proceed to investigation; decision to proceed to investigation; and decision pending. For situations in which the Prosecutor decided not to proceed to an investigation, we took note of the reasons, with the options being: preconditions to jurisdiction not met; subject-matter jurisdiction not met; inadmissible (complementarity); inadmissible (gravity); and investigation would not serve the interests of justice. These categories track closely with the criteria found in article 53(1) of the Rome Statute while allowing for a more specific analysis of the data.

The fourth criterion was the preliminary examination's duration, based on the best information that is publically available. For the starting date, we recorded the date that the preliminary

\footnotetext{
50 See Grey and Wharton, supra note 5.

51 This classification is done to the best of our ability based on the information made available by the OTP. In situations in which there is a state referral or article 12(3) declaration, we have taken this to be the initial trigger for the preliminary examination due to the Prosecutor's policy of automatically opening a preliminary examination upon receipt of a referral or a declaration (as opposed to an article 15 communication) unless there is a clear statement that there was already a preliminary examination underway prior to the receipt of the referral or declaration.
} 
examination was opened ${ }^{52}$ or, where that date is unknown, the date that it was announced ${ }^{53}$ or the date that the relevant Security Council referral, ${ }^{54}$ state referral, ${ }^{55}$ or article $12(3)$ declaration was received. ${ }^{56}$

${ }^{52}$ For example, the Government of Ukraine submitted its initial Article 12(3) declaration on 17 April 2014 and the OTP announced that it opened a preliminary examination into the situation in Ukraine just over a week later on 25 April 2014. Thus, a start date of 25 April 2014 was used. ICC-OTP, Report on Preliminary Examination Activities 2014, 2 December 2014, online: <https://www.icc-cpi.int/iccdocs/otp/otp-pre-exam-2014.pdf> (accessed 16 August 2018) at paras 58-59 [2014 PE Report]. Similarly, the OTP has stated that the situation in Gabon has been under preliminary examination since 29 September 2016, eight days after the receipt of the state referral. ICC-OTP, Report on Preliminary Examination Activities 2017, 4 December 2017, online: < https://www.icc-cpi.int/itemsDocuments/2017-PE-rep/2017-otp-repPE_ENG.pdf $>$ (accessed 16 August 2018) at paras 23-4 [2017 PE Report]. The preliminary examination in Kenya was opened on 27 December 2007. ICC-OTP, Situation in the Republic of Kenya, "Request for authorisation of an investigation pursuant to Article 15", 26 November 2009, ICC-01/09-3 at para. 3 [Kenya Request for Authorization]. The preliminary examination in Georgia was opened on 14 August 2008. ICC-OTP, Situation in Georgia, "Corrected Version of 'Request for authorisation of an investigation pursuant to article 15', 16 October 2015, ICC-01/15-4-Corr”, 17 November 2015 , ICC-01/15-4-Corr2 at para. 38 [Georgia Request for Authorization]. The situation in Guinea has been under preliminary examination since 14 October 2009; the Palestine II preliminary examination was opened on 16 January 2015; and the Burundi preliminary examination opened on 25 April 2016. 2017 PE Report, infra at paras 51, 156 \& 282. The preliminary examination in the CAR II Situation was opened on 7 February 2014. CAR II Article 53(1) Report, supra note 48, at para. 4. Both the Venezuela II and the Philippines preliminary examinations were opened on 8 February 2018 and the Bangladesh/Myanmar preliminary examination was opened on 18 September 2018. 2018 PE Report, supra note 16 at paras 25, 42 \& 99. The Colombia preliminary examination has been opened "since June 2004," thus we used the last day of the month for the purposes of any calculations. Colombia Interim Report, supra note 48, at para. 2. Finally, the OTP has stated that the preliminary examination in Afghanistan has been open "since 2006". ICC, Situation in the Islamic Republic of Afghanistan, "Public redacted version of 'Request for authorisation of an investigation pursuant to article 15’, 20 November 2017, ICC-02/17-2-Conf-Exp”, p-T. Ch. III, 20 November 2017, ICC-02/17-7-Red at para. 22. As no further information is available as to this preliminary examination's starting date, we used the last day of 2006 for the purposes of our calculations. Thus, we can say that it lasted at least as long as this calculated amount.

53 As the decision to open some of the earlier preliminary examinations were not initially made public, the "opening date" indicates that the preliminary examination was opened "at least as early as" a particular date at which point preliminary examination was made public. The preliminary examinations in Nigeria and Honduras were both announced on 18 November 2010. 2017 PE Report, supra note 52, at para. 204; "Honduras: Preliminary Examination", ICC Website. <https://www.icc-cpi.int/honduras> (accessed 16 August 2018) [Honduras Preliminary Examination]. The preliminary examination in South Korea was announced on 6 December 2010. South Korea Article 5 Report, supra note 48, at para. 2.

54 UN Security Council Resolution 1593, S/RES/1593, 31 March 2005 (re Darfur); UN Security Council Resolution 1790, S/RES/1790, 26 February 2011 (re Libya).

${ }^{55}$ Some state referrals were received subsequent to the opening of a preliminary examination. Thus, the referral date was only used as the date of the "opening" of the preliminary examination if it was the initial triggering mechanism for the preliminary examination. Situations for which the date of state referral was used include Uganda (referral date 16 December 2003), CAR I (referral date 22 December 2004), Mali (referral date 18 July 2012), and Comoros (referral date 14 May 2013). ICC, Prosecutor v. Dominic Ongwen, "Decision on the confirmation of charges against Dominic Ongwen", pT. Ch. III, 23 March 2016, ICC-02/04-01/15-422-Red at para. 4; ICC-OTP, "BACKGROUND: Situation in the Central African Republic”, The Hague, 22 May 2007, ICC-OTP-BN-20070522-220-A_EN, online: <https://www.icccpi.int/NR/rdonlyres/B64950CF-8370-4438-AD7C-0905079D747A/144037/ICCOTPBN20070522220_A_EN.pdf> (accessed 16 August 2018) [CAR Background]; Mali Article 53(1) Report, supra note 48, at para. 2; Comoros Article 53(1) Report, supra note 48, at para. 7.

56 The article 12(3) declaration from Côte d'Ivoire was received by the Prosecutor on 1 October 2003. ICC-OTP, Situation in the Republic of Côte d'Ivoire, "Request for authorisation of an investigation pursuant to article 15", 23 June 2011, ICC-02/11-3 at para. 15 [Côte d'Ivoire Request for Authorization]. The attempted article 12(3) declaration from Palestine which triggered the Palestine I preliminary examination was submitted on 22 January 2009. ICC-OTP, Report on Preliminary Examination Activities 2012, November 2012, online: <https://www.icc-cpi.int/NR/rdonlyres/C433C4627C4E-4358-8A72-8D99FD00E8CD/285209/OTP2012ReportonPreliminaryExaminations22Nov2012.pdf> (accessed 16 August 2018) at para. 196 [2012 PE Report]. 
Due to information gaps, some modifications to this method were necessary. For example, for the preliminary examinations in Afghanistan and the $\mathrm{DRC}$, the specific start date is unknown but there is some public information that allows us to approximate the start date. ${ }^{57}$ Moreover, for the first Venezuela preliminary examination, there is no available information on the start date. Hence, the approximate duration of the preliminary examination could not be calculated. ${ }^{58}$ There is similarly no available information on the initial start date of the Iraq/UK preliminary examination; ${ }^{59}$ all that it is known is the date on which this preliminary examination was "re-opened". 60

\footnotetext{
${ }^{57}$ Regarding Afghanistan, see note 52, above. Regarding the DRC, the OTP did not use the language of "preliminary examinations" this early in its practice. However, the OTP stated in a press release dated 16 July 2003 that it would "closely follow the situation" in the DRC, which indicates that a preliminary examination was in substance opened on that date. The OTP's subsequent press release of 23 June 2004 further supports that inference. ICC-OTP, Press Release, "Communications received by the Office of the Prosecutor of the ICC" 16 July 2003, online: <https://www.icc-cpi.int/NR/rdonlyres/B080A3DD-7C69-4BC9-AE250D2C271A9A63/277502/16_july__english.pdf> (accessed 6 September 2018); ICC-OTP, Press Release, "Office of Prosecutor of International Criminal Court Opens First Investigation” 23 July 2004, online: <https://www.un.org/press/en/2004/13071.doc.htm> (accessed 12 December 2018).

58 The first public statement in relation to this preliminary examination was the announcement that it was closed. ICCOTP, "Letter to communication senders concerning the situation in Venezuela", The Hague, 9 February 2006, online: <https://www.legal-tools.org/doc/c90d25/pdf> (accessed 16 August 2018) [Venezuela Letter]. ${ }^{59}$ ICC-OTP, "Letter to communication senders concerning the situation in Iraq", The Hague, 9 February 2006, online: <http://www.iccnow.org/documents/OTP_letter_to_senders_re_Iraq_9_February_2006.pdf> (accessed 16 August 2018) [Iraq Letter].

${ }^{60} \mathrm{It}$ is known that Prosecutor Bensouda re-opened the Iraq/UK preliminary examination on 13 May 2014, thus the most that can be said is that this preliminary examination has been ongoing at least as long as the duration since it has been re-opened. 2017 PE Report, supra note 52, at para. 172.
} 
For the end date, we recorded the date that the Prosecutor either decided to: open an investigation ${ }^{61}$ or seek judicial authorization to do so, ${ }^{62}$ or to close the preliminary examination (where the Prosecutor decided that there was not a reasonable basis to proceed. ${ }^{63}$ Finally, for those preliminary examinations that remain ongoing, the currency date of the 2018 Preliminary Examination Report (30 November 2018) was used to calculate the duration of these preliminary examinations thus far.

Fifth, to the extent possible, we recorded the time spent by the OTP, during the preliminary examination, determining whether or not the Court had jurisdiction and whether or not potential cases would be admissible to the ICC. While the OTP says that it conducts its preliminary examinations holistically and, thus, will continue to gather and analyze all relevant information throughout the preliminary examination, its Policy Paper on Preliminary Examinations indicates that the Office approaches the article 53(1) criteria of jurisdiction, admissibility, and "interests of justice" and sequentially. ${ }^{64}$

${ }^{61}$ ICC-OTP, Press Release, "Prosecutor of the International Criminal Court Opens an Investigation into Northern Uganda”, 29 July 2004, ICC-OTP-20040729-65, online: <https://www.icc-

cpi.int $/$ pages $/$ item.aspx?name $=$ prosecutor + of + the + international + criminal + court + opens + an + investigation + into + noth ern+uganda> (accessed 16 August 2018); CAR Background, supra note 55 (conclusion date 22 May 2007); ICC, Situation in the Libyan Arab Jamabiriya, "Decision on the Prosecutor's Application Pursuant to Article 58 as to Muammar Mohammed Abu Minyar Gaddafi, Saif Al-Islam Gaddafi and Abdullah Al-Senussi”, p-T. Ch. I, 27 June 2011, ICC01/11-01/11-1 at para. 2 (conclusion date 3 March 2011); ICC, Prosecutor v. Omar Hassan Al Bashir, "Decision on the Prosecution's Application for a Warrant of Arrest against Omar Hassan Al Bashir”, p-T. Ch. I, 4 March 2009, ICC02/05-01/09-3 at para. 3 [First Al Bashir Arrest Warrant Decision] (OTP notified Pre-Trial Chamber of decision to proceed to investigation in situation in Darfur, Sudan on 1 June 2005); Mali Article 53(1) Report, supra note 48; CAR II Article 53(1) Report, supra note 48. For the preliminary examination in the DRC, we have considered the preliminary examination concluded at the point at which the Prosecutor informed the ASP that he was ready to request authorization to open an investigation. This was said to happen in September 2003. Thus, the last date of this month was used for the purposes of calculating the duration of the preliminary examination. ICC, Assembly of States Parties, Third Session, "Report on the activities of the Court, 22 July 2004, ICC-ASP/3/10 at para. 55.

${ }^{62}$ In particular, the date on which the Prosecutor notified the President of the Court of his or her intention to submit a request for authorization to open an investigation proprio motu. Côte d'Ivoire Request for Authorization, supra note 56, at para. 8 (date of notification 19 May 2011); 2017 PE Report, supra note 52, at para. 231 (re Afghanistan - date of notification 30 October 2017) and para. 283 (re Burundi - date of notification 17 August 2017); Kenya Request for Authorization, supra note 52, at para. 1 (date of notification 5 November 2009); Georgia Request for Authorization, supra note 52, at para. 17 (date of notification 5 October 2015).

${ }^{63}$ Comoros Article 53(1) Report, supra note 48; Venezuela Letter, supra note 58; 2012 PE Report, supra note 56, at para. 196 (re Palestine I, date of conclusion 3 April 2012); Honduras Preliminary Examination, supra note 53 (date of conclusion 28 October 2015); "Preliminary Examination: Republic of Korea", ICC Website, online: <https://www.icccpi.int/korea> (accessed 16 August 2018) (date of conclusion 23 June 2014); Gabon Article 5 Report, supra note 48. ${ }^{64}$ PE Policy Paper, supra note 33, at para. 77. 
To make the most of the available information, our study also considers correlations between different data series. For example, it considers correlations between the triggers for preliminary examinations and their duration, among others. As shown below, these correlations shed light on the OTP's practice in opening, closing, and conducting preliminary examinations.

Finally, with respect to nomenclature, two points should be clarified. First, certain preliminary examinations relate to crimes allegedly committed in states that have already been the subject of a preliminary examination before. These include the Central African Republic (CAR), Palestine, and Venezuela, each of which lends its name to two distinct preliminary examinations concerning different alleged crimes. The OTP itself has adopted the sequential numbering of the "CAR I" and "CAR II" situations and we have followed this approach with respect to both Palestine I and II and Venezuela I and II for clarity. ${ }^{65}$ By contrast, we regard the preliminary examination regarding crimes allegedly committed by UK national in Iraq as one preliminary examination, noting that it was closed in 2006 but then "re-opened" in 2014. ${ }^{66}$

Second, the OTP's practice of naming situations is inconsistent. In some cases, it labels situations according to the state on whose territory the alleged crimes occurred, notwithstanding the nationality of the alleged perpetrators; ${ }^{67}$ in other cases, it labels situations according to the state where some of the alleged crimes occurred; ${ }^{68}$ and in others it also references the state of the alleged perpetrators. ${ }^{69}$ While this naming practice is inconsistent, it is followed here for simplicity.

\footnotetext{
${ }^{65}$ Numbered sequentially according to their date of opening.

${ }^{66}$ ICC, "Prosecutor of the International Criminal Court, Fatou Bensouda, re-opens the preliminary examination of the situation in Iraq", 13 May 2014, online: <https://www.icc-cpi.int/Pages/item.aspx?name=otp-statement-iraq-13-052014> (accessed 16 August 2018) [Prosecutor Re-Opens Preliminary Examination of the Situation in Iraq].

${ }^{67}$ For example, "the situation in the Republic of Korea" concerned crimes allegedly committed in that state by nationals of North Korea. See South Korea Article 5 Report, supra note 48.

${ }^{68}$ For example, the "situation in Afghanistan" concerns crimes allegedly committed in that state and in CIA-operated facilities in Poland, Romania and Lithuania. ICC-OTP, Situation in the Islamic Republic of Afghanistan, "Public redacted version of 'Request for authorisation of an investigation pursuant to article 15', 20 November 2017, ICC-02/17-ConfExp”, 20 November 2017, ICC-02/17-7-Red at para. 49 [Afghanistan Request for Authorization].

${ }^{69}$ For example, the "Iraq/UK" situation concerns crimes allegedly committed in Iraq by UK nationals.
} 


\section{FINDINGS: 15 YEARS OF PRELIMINARY EXAMINATIONS}

\section{A. TRIGGERS FOR PRELIMINARY EXAMINATIONS}

Of the twenty-seven preliminary examinations analyzed, five $(19 \%)$ were triggered by a state party referral, ${ }^{70}$ two $(7 \%)$ were triggered by UN Security Council referral, ${ }^{71}$ four $(15 \%)$ were triggered by the Prosecutor proprio motu following the receipt of an article $12(3)$ declaration, ${ }^{72}$ and sixteen (59\%) were triggered by the Prosecutor proprio motu without an article $12(3)$ declaration. ${ }^{73}$ Given that the majority of preliminary examinations were opened proprio motu without an Article 12(3) declaration (and thus were likely opened on the basis of article 15 communications), this suggests that the Court is, to some degree, fulfilling its goal of being an international institution which is not wholly controlled by states, but one in which victims, individuals, and civil society organizations can have recourse to as well (although state actors can also submit article 15 communications, and have done so). ${ }^{74}$

${ }^{70}$ Uganda, CAR I, Mali, Comoros, and Gabon.

${ }^{71}$ Darfur, Sudan, and Libya.

${ }^{72}$ Côte d'Ivoire, Palestine I, Ukraine, and Palestine II.

${ }^{73}$ DRC, Colombia, Iraq/UK, Venezuela I, Kenya, Afghanistan, Georgia, Guinea, Republic of Korea, Nigeria, Honduras, CAR II, Burundi, the Philippines, Venezuela II, and Bangladesh/Myanmar.

${ }^{74}$ See example in Part $\mathrm{D}(1)$ below. 
Figure 1: Triggers for preliminary examinations (as at 30 November 2018)

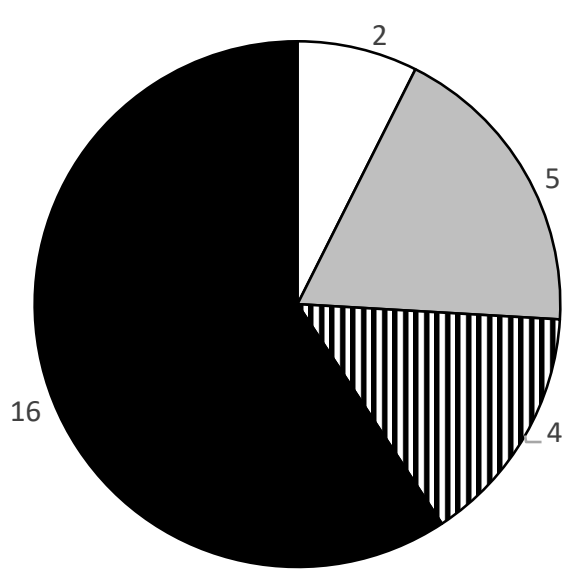

口UN Security Council referral

$\square$ State party referral

DProsecutor with Art. 12(3) declaration

- Prosecutor without Art. 12(3) declaration

\section{B. INFORMATION SEEKING AT THE PRELIMINARY EXAMINATION STAGE}

At the preliminary examination stage, the OTP has "limited powers at its disposal". ${ }^{75}$ Notwithstanding that constraint, the OTP has considerable scope to gather information at this stage of proceedings. The Rome Statute says that, in order to analyse the seriousness of the information received at this stage, the Prosecutor "may seek additional information from States, organs of the United Nations, intergovernmental or non-governmental organizations, or other reliable sources that he or she deems appropriate," and may also "receive written or oral testimony at the seat of the Court."76

In practice, the OTP has made full use of these powers. Far from adopting a passive role at the preliminary examination stage, it undertakes numerous information-seeking activities including conducting missions to relevant states and hosting and participating in meetings at the seat of the Court and other locations during which it engages with relevant stakeholders including state officials,

\footnotetext{
75 Iraq Letter, supra note 59, at 2; PE Policy Paper, supra note 33, at para. 85.

${ }^{76}$ Rome Statute, supra note 23, Article 15(2).
} 
victims and victim representative organizations, international and local NGOs. The OTP also reviews open source information. For example, in its 2018 preliminary examination report, the OTP stated that, in the reporting year, "the Office sent preliminary examination missions to Abuja, Bogota, Conakry, and Kyiv and held numerous consultations at the seat of the Court with State authorities, representatives of international and non-governmental organisations, article 15 communication senders and other interested parties."

When possible, the OTP conducts missions to the relevant states in the conduct of its preliminary examinations in order to verify information received about alleged crimes and to engage with local stakeholders and judicial actors. For example, since opening the Guinea preliminary examination in September 2009, the OTP has conducted sixteen missions to that country. ${ }^{78}$ Since announcing the Georgia preliminary examination in August 2008, it has conducted nine missions regarding that situation: six in Georgia, and three to Russia. ${ }^{79}$ In relation to the situation in Colombia, the OTP conducted three missions to that country in 2018 alone. ${ }^{80}$ During these and other preliminary examination missions, the OTP met with political and judicial authorities, as well as representatives of intergovernmental organizations, NGOs, and victims. ${ }^{81}$ The Prosecutor has also met with numerous heads of states including the presidents of Palestine, Colombia, Guinea, and Nigeria, to discuss relevant preliminary examinations. ${ }^{82}$ However, the OTP has struggled to conduct missions to the relevant states on some occasions. It was not able to conduct its first mission to Afghanistan until

\footnotetext{
772018 PE Report, supra note 16, at para. 23.

782018 PE Report, supra note 16 at para. 180.

${ }^{79}$ Georgia Request for Authorization, supra note 52, at para. 39.

802018 PE Report, supra note 16, at para. 161.

812017 PE Report, supra note 52, at paras 48, 116, 169 \& 233. ; ICC-ASP, "Report on the activities of the Court", Ninth Session, ICC-ASP/9/23, 19 November 2010 at para. 62; 2012 PE Report, supra note 56, at paras 160 \& 162; ICC-OTP, Report on Preliminary Examination Activities 2013, November 2013, online: <https:/ /www.icccpi.int/OTP\%20Reports/otp-report-2013.aspx> (accessed 17 August 2018) at para. 197 [2013 PE Report]; and 2014 PE Report, supra note 52, at para. 165.

822012 PE Report, supra note 56, at paras 94 \& 160; 2013 PE Report, supra note 81, at para. 150; Report of the International Criminal Court to the Seventy-first session of the UN General Assembly, UNGAOR, A/71/342, 19 August 2016 at para. 24.
} 
2013, even though it had been conducting a preliminary examination in the situation since $2006 .{ }^{83}$ Similarly, the OTP was unsuccessful for years in its attempts to conduct a mission to Côte d'Ivoire. ${ }^{84}$ The OTP has also used the preliminary examination process to promote "positive complementarity", meaning that it seeks to encourage and support genuine domestic proceedings. ${ }^{85}$ For example, the OTP met with the President of the Criminal Appellate Division of the Colombian Supreme Court, participated in a conference on "Strengthening the Attorney General's office on Transitional Justice", and met with the President of Colombia's Constitutional Court amongst other liaison activities to support such positive complementarity efforts. ${ }^{86}$ The Prosecutor even submitted an amicus curiae brief to the Constitutional Court of Colombia with respect to certain Colombian transitional justice legislation. ${ }^{87}$

In accordance with the Statute, the Office also requests relevant information at the preliminary examination stage. For example, in the context of its preliminary examination in Georgia, the OTP has made a total of fourteen formal requests for information, "six to the Government of Georgia, four to the Government of the Russian Federation, three to the Organization for Security and Cooperation in Europe (OSCE) and one to the European Court of Human Rights". ${ }^{8}$ The OTP meets with varying success with respect to these formal requests. In the context of its Afghanistan preliminary examination, the OTP submitted 29 formal requests but only received 15 responses. ${ }^{89}$ In its preliminary examination in the situation in South Korea, the OTP sought and received information

\footnotetext{
83 Afghanistan Request for Authorization, supra note 68, at para. 26.

84 ICC-ASP, Report on the activities of the Court, Sixth Session, 18 October 2007, ICC-ASP/6/18 at para. 37; ICC-ASP, Report on the activities of the Court, Seventh Session, 29 October 2008, ICC-ASP/7/25 at para. 68; ICC-ASP, Report on the activities of the Court, Eighth Session, 21 October 2009, ICC-ASP/8/40 at para. 60.

85 PE Policy Paper, supra note 33, at paras 100-03. For a recent evaluation of the effectiveness of this "positive complementarity" approach, see: Human Rights Watch, "Pressure Point: The ICC's Impact on National Justice Lessons from Colombia, Georgia, Guinea, and the United Kingdom” (May 2018), Human Rights Watch, online: <https://www.hrw.org/sites/default/files/report_pdf/ij0418_web_0.pdf> (accessed 7 September 2009). 86 ICC-ASP, Report on the activities of the Court, Ninth Session, 19 November 2010, ICC-ASP/9/23, at para. 63; 2014 PE Report, supra note 52, at para. 128; 2017 PE Report, supra note 52, at para. 153.

872017 PE Report, supra note 52, at para. 153.

${ }^{88}$ Georgia Request for Authorization, supra note 52, at para. 39.

${ }^{89}$ Afghanistan Request for Authorization, supra note 68, at para. 23.
} 
from the Government of South Korea but received no response to its request to the Government of North Korea. ${ }^{90}$ In addition to formal requests for information, the OTP has solicited and received legal submissions to assist in its analysis of challenging legal questions that arise. For example, in its Palestine I preliminary examination, the OTP reported having considered " 15 legal submissions from experts, academics and NGOs on the issue of jurisdiction." 91

Finally, if the OTP concludes that there is a reasonable basis to open an investigation, and there is no state or Security Council referral, its work at the preliminary examination stage includes the preparation of a detailed request to the pre-trial chamber for authorization to commence an investigation. The OTP's most recent request, submitted upon completion of its preliminary examination in Afghanistan, totaled 181 pages of written submissions (plus numerous annexes). ${ }^{92}$

As shown in this brief outline, preliminary examinations constitute a significant part of the OTP's work. Far from waiting for information to arrive at its doors, the Office proactively seeks information from a wide range of sources, engages extensively with external actors, and expends considerable energy promoting "positive complementarity" as well.

\section{LEGAL FINDINGS ON ARTICLE 53(1) CRITERIA}

In terms of internal activities, the OTP's main task during a preliminary examination is for the Prosecutor to determine whether or not the statutory criteria for opening a preliminary examination are made out. As stated above, these criteria are found in article 53(1) of the Rome Statute and relate to "jurisdiction", "admissibility", and the "interest of justice".

\footnotetext{
${ }^{90}$ South Korea Article 5 Report, supra note 48, at para. 5.

${ }^{91}$ Report of the International Criminal Court to the Sixty-fifth session of the UN General Assembly, UNGAOR, A/65/313, 19 August 2010, at para. 82 [Report of ICC to $65^{\text {th }}$ Session of UNGA].

92 Afghanistan Request for Authorization, supra note 68.
} 


\section{Jurisdiction}

In determining whether or not there is a reasonable basis to believe that crimes within the ICC's jurisdiction have been committed, the Office must first consider whether certain preconditions to jurisdiction are satisfied. Specifically, with the exception of Security Council referrals, the alleged crimes must have been committed on the territory of a state that has accepted the ICC's jurisdiction (either by ratifying the Rome Statute, or making a declaration under article 12(3)), or by a national of such a state.

This issue proved contentious in the Palestine I preliminary examination, which was triggered in 2009 when the Palestinian National Authority (PNA) attempted to submit an article 12(3) declaration accepting the jurisdiction of the ICC. ${ }^{93}$ The OTP also received 400 article 15 communications relating to Palestine. ${ }^{94}$ However, without the consent of a relevant state or a Security Council referral, the Prosecutor had no legal basis to proceed on these communications. Thus, the ability of the Prosecutor to act in this situation depended on the validity of the article 12(3) declaration. Ultimately, the Prosecutor closed this preliminary examination on 3 April 2012 based on its conclusion that the Court lacked jurisdiction because the statehood of Palestine was not at that time confirmed by the UN General Assembly and, thus, the PNA did not have the capacity to lodge an article 12(3) declaration. ${ }^{95}$ This situation is noteworthy because on other occasions, including an attempted article 12(3) declaration by the Freedom and Justice Party in Egypt and proceedings relating to Myanmar and Bangladesh, the OTP has made its conclusion on whether the preconditions to jurisdiction are satisfied before a preliminary examination has formally begun. ${ }^{96}$

\footnotetext{
932012 PE Report, supra note 56, at para. 196.

94 Seventh Report of the International Criminal Court to the United Nations for 2010/2011, UNGOAR, A/66/309, 9 August 2011 at para. 84.

952012 PE Report, supra note 56, at paras 196 \& 201.

${ }^{96}$ See Grey and Wharton, supra note 5.
} 
If satisfied that the preconditions to jurisdiction are fulfilled, the OTP must next consider whether the alleged crimes fall within its temporal and subject-matter jurisdiction. The Prosecutor has closed four preliminary examinations on this basis. The first occasion was in 2006, when the (then) Prosecutor closed the Venezuela I preliminary examination. The OTP stated that it had received 12 communications relating to this situation but that some communications related to crimes committed in the context of a failed coup in April 2002 and, thus, pre-dated the temporal jurisdiction of the Court. ${ }^{97}$ The other communications related to allegations of crimes committed by the government of Venezuela against its political opponents but were criticized as being "very generalized", "not [...] substantiated by analysis of open source information", and rife with inconsistencies. ${ }^{98}$ Thus, the Prosecutor concluded that there was no reasonable basis to believe that crimes against humanity were

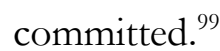

The next occasion was in June 2014 when Prosecutor Bensouda closed the South Korea preliminary examination that began in 2010, which concerned war crimes allegedly committed during the sinking of the South Korean warship Cheonan in the Yellow Sea and the shelling of South Korea's Yeongpyeong Island by North Korea. ${ }^{100}$ While the OTP concluded that the chapeau requirement of an international armed conflict was established and that the Court could exercise jurisdiction on the basis of objective territoriality, it concluded that the specific elements of relevant war crimes were not made out. $^{101}$

The third example was in 2015 when the OTP closed the preliminary examination that it had been conducting in the situation in Honduras. ${ }^{102}$ This preliminary examination initially focused on

\footnotetext{
97 Venezuela Letter, supra note 58.

98 Ibid.

${ }^{99}$ Ibid.

100 South Korea Article 5 Report, supra note 48, at para. 2.

101 Ibid at paras $39 \& 43-81$.

102 Honduras Article 5 Report, supra note 48.
} 
alleged crimes against humanity in the aftermath of the June 2009 coup d'etat. In November 2013, the Prosecutor reached an initial conclusion that there was no reasonable basis to believe that there was a widespread or systematic attack in the aftermath of the coup and, thus, the acts in question did not amount to crimes against humanity. ${ }^{103}$ Despite this, the OTP continued its preliminary examination in light of further allegations of crimes committed in the Bajo Aguán region of the country. Ultimately, in 2015 the OTP concluded that these alleged crimes may have been linked to the rise of drug trafficking in the country but, again, did not amount to crimes against humanity. ${ }^{104}$

Most recently, the OTP closed its preliminary examination into the situation in Gabon on 21 September 2018. ${ }^{105}$ Following the submission of a state referral by the Government of Gabon on 21 September 2016, the OTP opened a preliminary examination in relation to post-election violence in the country eight days later (the OTP also reported having received eighteen article 15 communications in relation to this situation). ${ }^{106}$ However, the Prosecutor ultimately concluded that the available information did not provide a reasonable basis to believe that allegations against both state security forces and opposition forces amounted to crimes against humanity nor did allegations against opposition leader amount to incitement to commit genocide. ${ }^{107}$ Accordingly, the Prosecutor closed the preliminary examination on the basis of lack of subject-matter jurisdiction.

As to ongoing assessments, the OTP is currently analyzing jurisdiction in the preliminary examinations in Ukraine, the Philippines, Venezuela II, and Bangladesh/Myanmar. The preliminary examination in Ukraine was opened on 25 April 2014 following the submission of an article 12(3)

\footnotetext{
1032013 PE Report, supra note 81, at at paras 71-73.

104 ICC-OTP, Report on Preliminary Examination Activities (2015), 12 November 2015, online: <https://www.icccpi.int/iccdocs/otp/otp-pe-rep-2015-eng.pdf> (accessed 17 August 2018) at paras 276 \& 278 [2015 PE Report].

105 Gabon Article 5 Report, supra note 48.

106 Ibid at paras 3-9.

107 Ibid at paras 16-20. See also 2018 PE Report, supra note 16 at paras 285-312.
} 
declaration by the Government of Ukraine. ${ }^{108}$ That government then lodged a second article 12(3) declaration on 8 September 2015, extending the timeframe of the acceptance of jurisdiction. ${ }^{109}$ In addition, the OTP has received eighty-six article 15 communications in relation to this situation. ${ }^{110}$ This preliminary examination focuses on allegations in three related contexts: the protests that erupted in Kyiv's Maidan square in 2013; Crimea; and Eastern Ukraine. ${ }^{111}$ In 2015, the OTP concluded that there was a reasonable basis to believe that the suppression of the "Maidan protests" was an attack against a civilian population pursuant to a state policy, but that the attack was neither widespread nor systematic and, thus, no crimes against humanity were committed. ${ }^{112}$ The OTP has continued its assessment of subject-matter jurisdiction in the other contexts including the Russian seizure and annexation of Crimea and in relation to fighting between the Ukrainian government and antigovernment forces in the Donbas region of Eastern Ukraine, including the shooting down of Malaysian Airlines flight MH17. ${ }^{113}$

On 8 February 2018, Prosecutor Bensouda opened two new preliminary examinations proprio motu in the situations in the Philippines and Venezuela II. ${ }^{114}$ The Philippines preliminary examination focuses on alleged crimes perpetrated in the context of "the so-called "war on drugs" including those "promoted and encouraged" by Philippine President Rodrigo Duterte and other senior government

\footnotetext{
108 Embassy of Ukraine to the United Kingdom of the Netherlands, "Letter transmitting Article 12(3) declaration", 9 April 2014, online: <https://www.icc-cpi.int/itemsDocuments/997/declarationRecognitionJurisdiction09-04-2014.pdf> (accessed 4 August 2018). See also 2014 PE Report, supra note 52, at para. 59.

${ }^{109}$ Letter from Pavlo Klimkin, Minister of Foreign Affairs of Ukraine, to Mr. Herman von Hebel, Registrar of the International Criminal Court, 8 September 2015, available online: <https:/ /www.icccpi.int/iccdocs/other/Ukraine_Art_12-3_declaration_08092015.pdf> (accessed 17 August 2018).

1102018 PE Report, supra note 16, at para. 59.

111 Ibid at paras 84-95.

1122015 PE Report, supra note 104, at paras 91-8.

113 Ibid at para. 86; ICC-OTP, Report on Preliminary Examination Activities 2016, 14 November 2016, online:

<https://www.icc-cpi.int/iccdocs/otp/161114-otp-rep-pe_eng.pdf> (accessed 16 August 2018) at paras 155-58, 16- \& 164-179 [2016 PE Report]; 2018 PE Report, supra note 16 at paras 66 - 93.

114 The Prosecutor reported having received 52 article 15 communications in relation to the situation in the Philippines and 110 article 15 communications in relation to the situation in Venezuela II. 2018 PE Report, supra note 16 at paras 42 $\& 99$.
} 
officials. ${ }^{115}$ The Venezuela II preliminary examination relates to allegations of crimes against humanity perpetrated "in the context of demonstrations and related political unrest" in the country since early 2017. ${ }^{116}$ Interestingly, the Venezuela II situation is the first for which a state referral was made (post hoc) ${ }^{117}$ from states other than the territorial state (i.e. the first non-self-referral). This referral was made jointly by six states from the Americas, namely the Argentine Republic, Canada, the Republic of Colombia, the Republic of Chile, the Republic of Paraguay, and the Republic of Peru, on 26 September $2018 .^{118}$

Finally, on 18 September 2018, Prosecutor Bensouda announced that she was opening a preliminary examination proprio motu in relation to the alleged deportation of Rohingya people from Myanmar to Bangladesh, and possible other crimes, after receiving thirty-four article 15 communications relating to this situation. ${ }^{119}$ This announcement followed a decision issued by PreTrial Chamber I, upon application from the OTP, which concluded that the Court could exercise jurisdiction over the alleged deportation of Rohingya people from Myanmar into Bangladesh, and possibly other crimes against humanity as well. ${ }^{120}$ The Chamber reasoned that, although Myanmar is not a state party to the Rome Statute, the Court had jurisdiction because the alleged deportation occurred in part in Bangladesh, which is a state party. ${ }^{121}$

\footnotetext{
1152018 PE Report, supra note 16 at paras 51-53.

116 Statement of OTP on opening Philippines and Venezuela II Preliminary Examinations, supra note 2 . See also 2018 PE Report, supra note 16 at paras 104-116.

117 We use the term "post hoc referral" to refer to situations in which the OTP has already commenced a preliminary examination proprio motu and the state subsequently makes a referral regarding the same situation, thereby vitiating the need for authorization from a pre-trial chamber to proceed to an investigation.

118 ICC-OTP, "Prosecutor of the International Criminal Court, Mrs Fatou Bensouda, on the referral by a group of six States Parties regarding the situation in Venezuela", 27 September 2018, online: <https://icccpi.int/Pages/item.aspx?name=180927-otp-stat-venezuela $>$ (accessed 7 November 2018); ICC, "Referral of the situation in Venezuela under Article 14 of the Rome Statute submitted by the Republic of Argentina, Canada, the Republic of Colombia, the Republic of Chile, the Republic of Paraguay and the Republic of Peru", 26 September 2018, online: <https://www.icc-cpi.int/itemsDocuments/180925-otp-referral-venezuela_ENG.pdf> (accessed 7 November 2018).

1192018 PE Report, supra note 16 at paras 25 \& 37-38.

120 Ibid, paras 26-29.

${ }^{121}$ ICC, Request Under Regulation 46(3) of the Regulations of the Court, "Decision on the 'Prosecution's Request for a Ruling on Jurisdiction under Article 19(3) of the Statute", p-T. Ch. I, 6 September 2018, ICC-RoC46(3)-01/18-37 [PTC
} 


\section{Admissibility}

After considering jurisdiction, the OTP must determine whether or not potential future cases would be admissible to the ICC in accordance with article 17 of the Rome Statute. The first consideration here is the principle of "complementarity", which limits admissible cases to those not investigated or prosecuted genuinely by the relevant domestic courts. ${ }^{122}$ While there are no actual "cases" at the preliminary examination phase, the Prosecutor must assess whether any potential cases would be admissible. To date, no preliminary examinations have been closed on the basis of inadmissibility due to complementarity. This is likely, at least in part, a result of the OTP's commitment to "positive complementarity", that is, its commitment to encouraging genuine national prosecutions of the alleged crimes.

Additionally, a case is inadmissible before the ICC if it "is not of sufficient gravity to justify further action by the Court." 123 On February 2006, the OTP announced that it was closing a preliminary examination into the Iraq/UK situation on this basis. ${ }^{124}$ While Iraq is not a state party to the Rome Statute, the allegations related to crimes allegedly committed by nationals of the UK, which is a state party, giving the ICC jurisdiction under article 12(2)(b) of the Rome Statute. The preliminary examination was opened on the basis of "over 240 " article 15 communications. ${ }^{125}$ The OTP concluded that, within its limited jurisdiction over what allegedly happened in Iraq, there was a reasonable basis to believe that the war crimes of wilful killing of approximately four to twelve victims and inhumane

Decision Regarding Myanmar and Bangladesh]; 2018 PE Report, supra note 16, paras 31-33. In a partially dissenting opinion, Judge Perrin de Brichambaut held that at the present stage of proceedings, the Court could not rule on the question of jurisdiction over the alleged deportation of the Rohingya people. ICC, Request Under Regulation 46(3) of the Regulations of the Court, "Decision on the 'Prosecution's Request for a Ruling on Jurisdiction under Article 19(3) of the Statute: Partially Dissenting Opinion, Judge Perrin de Brichambaut, 6 September 2018, ICC-RoC46(3)-01/18-37-Anx.

122 Rome Statute, supra note 23, Article 17(1)(a)-(c).

123 Ibid at Article $17(1)(\mathrm{d})$.

124 Iraq Letter, supra note 59.

125 Ibid at 1. 
treatment of less than twenty victims had been perpetrated. ${ }^{126}$ Nonetheless, it ultimately concluded that this did not meet the required gravity threshold and, thus, was not admissible. ${ }^{127}$ Accordingly, the OTP closed the preliminary examination with a decision not to proceed to an investigation. However, on 13 May 2014, Prosecutor Bensouda "re-opened" this preliminary examination on the basis of new information relating to the allegations. ${ }^{128}$

The Comoros preliminary examination was the second to be closed due to a conclusion of insufficient gravity, and the only preliminary examination to remain closed on that basis. The preliminary examination was initiated as a result of a state party referral by Comoros concerning the 2010 interception of a humanitarian aid flotilla destined for Gaza by the Israeli Defence Forces on ships registered to Comoros, Greece and Cambodia, which resulted in the death of ten people on the vessel registered to Comoros (the Mavi Marmara) and the mistreatment of other passengers. ${ }^{129}$ The OTP concluded that there was a reasonable basis to believe that war crimes were committed on the Mavi Marmara, however "the total number of victims of the flotilla incident reached relatively limited proportions as compared, generally, to other cases involved by the Office." 130 Accordingly, the preliminary examination was closed due to insufficient gravity. Comoros asked the Pre-Trial Chamber to review the Prosecutor's decision and to request that she re-consider. ${ }^{131}$ The Pre-Trial Chamber granted that request. ${ }^{132}$ This was the first and, thus far, the only time that such a request to the

\footnotetext{
126 Ibid at 4-8.

127 Ibid at 9.

128 Prosecutor Re-Opens Preliminary Examination of the Situation in Iraq, supra note 66. See Beth Van Schaack, "Backgrounder: Preliminary Examination into Abuses by United Kingdom Personnel in Iraq", Just Security (blog), 14 May 2014, online: <https://www.justsecurity.org/10457/backgrounder-preliminary-examination-united-kingdom-personnel$\mathrm{iraq} />$ (accessed 17 August 2017).

1292016 PE Report, supra note 113, at paras 314 \& 317-19; Comoros Article 53(1) Report, supra note 48, at paras 2, 5 \& $11-13$.

${ }^{130}$ Comoros Article 53(1) Report, supra note 48, at paras 19-128, 132 \& 138.

131 ICC, Situation on Registered Vessels of the Union of Comoros, The Hellenic Republic of Greece and the Kingdom of Cambodia, “Application for Review pursuant to Article 53(3)(a) of the Prosecutor's Decision of 6 November 2014 not to initiate an investigation in the Situation", 29 January 2015, ICC-01/13-3-Red [Comoros Application for Review].

132 ICC, Situation on the Registered Vessels of the Union of Comoros, The Hellenic Republic of Greece and the Kingdom of Cambodia, "Decision on the request of the Union of the Comoros to review the Prosecutor's decision not to initiate an investigation”, Judge Péter Kovács dissenting, p-T. Ch. I, 16 July 2015, ICC-01/13-34 [Comoros Decision to Review].
} 
Prosecutor has been made. On 29 November 2017, the Prosecutor released a "final decision" affirming her prior conclusion on the gravity threshold. ${ }^{133}$ A year later, a differently constituted PreTrial Chamber released yet another decision reiterating the request to the Prosecutor to reconsider her decision (the majority concluding that the Prosecutor did not adequately comply with the earlier PreTrial decision in her purported "final decision"). ${ }^{134}$ The Prosecutor has sought leave to appeal that decision. ${ }^{135}$ Thus, proceedings in relation to the Comoros situation linger on, more than four years after the Prosecutor's initial decision to close the preliminary examination.

As to other ongoing preliminary examinations, the OTP is still assessing admissibility in five situations: Colombia, Guinea, Nigeria, the re-opened Iraq/UK preliminary examination, and Palestine II. The preliminary examination in Colombia was opened in June 2004 (although it was not made public until later). ${ }^{136}$ It focuses on crimes against humanity and war crimes allegedly committed by government forces as well as members of non-state armed groups including the Fuerzas Armadas Revolucionarias de Colombia - Ejército del Pueblo (FARC-EP), Ejército de Liberación Nacional (ELN), and other paramilitaries. ${ }^{137}$ While the OTP has not clarified precisely when it concluded that there was a reasonable basis to believe that crimes within the jurisdiction of the Court had been committed in this situation, its reports show that this decision was made no later than 2010 at which point the OTP was

\footnotetext{
133 ICC-OTP, Situation on the Registered Vessels of the Union of the Comoros, the Hellenic Republic and the Kingdom of Cambodia, "Final decision of the Prosecution concerning the 'Article 53(1) Report' (ICC-01/13-6-AnxA), dated 6 November 2014”, 29 November 2017, ICC-01/13-57-Anx1.

134 ICC, Situation on the Registered Vessels of the Union of the Comoros, The Hellenic Republic and the Kingdom of Cambodia, "Decision on the "Application for Judicial Review by the Government of the Union of the Comoros"', p-T. Ch. I, 15 November 2018, ICC-01/13-68, Judge Péter Kovács dissenting in part [Comoros Decision on Application for Judicial Review]. In fact, the Pre-Trial Chamber states that the Prosecutor's "final decision" "wilfully refrains from complying with" its early decision requesting the Prosecutor to reconsider (at para. 119). The Pre-Trial Chamber set a six month time limit for the Prosecutor to conduct and report on such reconsideration.

135 ICC, Situation on Registered Vessels of the Union of the Comoros, the Hellenic Republic of Greece, and the Kingdom of Cambodia, "Request for Leave to Appeal the "Decision on the "Application for Judicial Review by the Government of the Union of the Comoros"”, p-T. Ch. I, 21 November 2018, ICC-01/13-69

${ }_{136}$ Colombia Interim Report, supra note 48, at para. 2. ${ }^{137} 2017$ PE Report, supra note52, para. 124; Colombia Interim Report, supra note 48, at paras 31-153.

1372017 PE Report, supra note52, para. 124; Colombia Interim Report, supra note 48, at paras 31-153.
} 
already focused on admissibility. ${ }^{138}$ Over the past few years, Colombia has sent the OTP hundreds of judgments that may relate to crimes within the Court's jurisdiction. ${ }^{139}$ Nonetheless, the OTP has kept open the preliminary examination, with no final decision on whether the potential ICC cases are already the subject of genuine national proceedings. ${ }^{140}$

On 14 October 2009, the OTP opened a preliminary examination in the situation in Guinea, focusing on the violent suppression of pro-democracy/anti-government protests by security forces in Conakry stadium on 28 September 2009. ${ }^{141}$ By 13 December 2011, the OTP had concluded that there was a reasonable basis to conclude that crimes against humanity had been committed in this situation. ${ }^{142}$ Since then, the OTP has been focused on its admissibility assessment. Despite the fact that Guinean authorities expressed a commitment to investigating and prosecuting these crimes for years and have taken significant investigatory steps towards such prosecutions, ${ }^{143}$ the OTP has kept its preliminary examination ongoing, noting in its 2018 report that the national investigation in Guinea has been completed and proceedings into the relevant case are underway. Therefore, the OTP's admissibility assessment has focused on whether the national authorities are willing and able to conduct those proceedings genuinely, "in particular whether proceedings are conducted with the intent to bring to justice the alleged perpetrators within a reasonable time frame."144

The preliminary examination in Nigeria was opened proprio motu by Prosecutor MorenoOcampo. It was made public on 18 November $2010^{145}$ but the OTP had been receiving article 15

\footnotetext{
138 Report of ICC to the $65^{\text {th }}$ Session of UNGA, supra note 91 , at para. 70.

1392017 PE Report, supra note 52, at para. 130; 2018 PE Report, supra note 16, at para. 134.

1402017 PE Report, supra note 52, at paras 130-42; 2018 PE Report, supra note 16, at para. 165.

${ }^{141}$ ICC-OTP, Report on Preliminary Examination Activities, 13 December 2011, online: <https://www.icccpi.int/NR/rdonlyres/63682F4E-49C8-445D-8C13-

F310A4F3AEC2/284116/OTPReportonPreliminaryExaminations13December2011.pdf> (accessed 16 August 2018) at paras 107-112 [2011 PE Report]; 2017 PE Report, supra note 52, at para. 158.

1422011 PE Report, supra note 141, at para. 113.

1432012 PE Report, supra note 56, at paras 153-58.

1442018 PE Report, supra note 16, at para. 172.

1452017 PE Report, supra note 52, at para. 204. In the Prosecutor's announcement, he mentions that "the Office has been analyzing the alleged crimes committed in Central Nigeria since mid-2004". This could suggest that the OTP has been conducting what amounts in substance to a preliminary examination for a long time prior to the announcement.
} 
communications over the preceding five years. ${ }^{146}$ This preliminary examination has considered numerous allegations in relation to three different regions and contexts within the country, including: "inter-communal, political and sectarian violence" in the Middle-Belt states; allegations of violence in the Niger Delta region; and alleged crimes committed by Boko Haram in the country's north-east. ${ }^{147}$ In its report of 5 August 2013, the OTP concluded that there was no reasonable basis to believe that the alleged crimes committed in the "inter-communal violence" and in the Niger Delta qualified as crimes within the jurisdiction of the Court, but that there was a reasonable basis to conclude that crimes against humanity were committed by Boko Haram. ${ }^{148}$ While the OTP continues to look into reports of new crimes in Nigeria, ${ }^{149}$ for the past five years it has focused primarily on the issue of admissibility, noting that although "there seems to be a tangible prospect of further proceedings against members of Boko Haram, including high-level commanders, at this stage the same cannot be said of the [National Security Forces]."150

In relation to the Iraq/UK preliminary examination, Prosecutor Bensouda "re-opened" this preliminary examination on 13 May 2014 on the basis of new article 15 communications. ${ }^{151}$ The OTP has since concluded that there was a reasonable basis to believe that members of the UK forces committed war crimes within the jurisdiction of the Court against at least 61 victims, ${ }^{152}$ and is now focusing on the issue of admissibility. ${ }^{153}$

\footnotetext{
However, the OTP also stated at this time that "the Office is still at the beginning of its preliminary examination work, in the process of determining whether or not Rome Statute crimes have been committed or not." Thus, it remains unclear how far in advance of this 2010 announcement the OTP was engaged in an active preliminary examination. ICCOTP, “OTP Weekly Briefing”, 16-22 November 2010, Issue \#64, online: <https:/ /www.icccpi.int/iccdocs/otp/OTP_Weekly_Briefing_64-ENG.pdf> (accessed 11 August 2018) at 2.

146 Nigeria Article 5 Report, supra note 48, at para. 4.

147 Ibid at paras 6-9 \& 26-32.

148 Ibid at paras 13-17, 40-62 \& 77-126.

1492018 PE Report, supra note 16, at paras 227-232.

150 Ibid at para. 249

151 Ibid at paras 173-74.

1522018 PE Report, supra note 16, at paras 194-196.

153 Ibid at paras 199-209.
} 
Subsequent to the failed attempt by Palestine to submit an Article 12(3) declaration in 2009, the UN General Assembly granted Palestine "non-member observer state" status in late $2012 .{ }^{154}$ This allowed Palestine to submit a valid article 12(3) declaration on 1 January 2015, prompting the OTP to open a preliminary examination on 16 January of that year. The day after the deposit of its article 12(3) declaration, Palestine deposited its instrument of accession to the Rome Statute making it a state party. In addition to Palestine's declaration, the OTP has received 125 communications in relation to alleged crimes committed in this context. ${ }^{155}$ As part of this preliminary examination, the OTP has stated that it is looking into crimes allegedly committed in relation to settlement activities in the West Bank and East Jerusalem and by both Palestinian armed groups as well as Israeli Defence Forces (IDF) during the conflict in Gaza in July-August 2014 and more recent violence along the Israel-Gaza border. ${ }^{156}$ The OTP has noted challenges that have arisen in the context of this preliminary examination, including certain (unspecified) "novel and/or complex legal issues” involved. ${ }^{157}$ In May 2018, Palestine submitted a post hoc state self-referral of the situation to the Court, thereby enabling the Prosecutor to open an investigation without judicial authorization should she be satisfied that the statutory criteria are satisfied. ${ }^{158}$ The OTP's 2018 report on preliminary examination activities indicates that it is continuing to assess subject matter jurisdiction in this situation, and is also considering the admissibility of potential cases in line with a "holistic" (as opposed to sequenced) assessment of the Article 53(1) criteria. ${ }^{159}$ The report states that the Office has reached an "advanced stage" of its assessment of those criteria in relation to Palestine ${ }^{160}$ and "intends to complete the preliminary

${ }^{154}$ UN, “General Assembly Votes Overwhelmingly to Accord Palestine 'Non-Member Observer State' Status in United Nations" (29 November 2012) United Nations: Meetings Coverage and Press Release online:

<https://www.un.org/press/en/2012/ga11317.doc.htm> (accessed 13 September 2018).

1552018 PE Report, supra note 16, at para. 251.

156 Ibid at paras 268-275.

1572017 PE Report, supra note 52, at para. 68.

158 The State of Palestine, "Referral by the State of Palestine Pursuant to Article 13(a) and 14 of the Rome Statute", 15 May 2018, online: <https://www.icc-cpi.int/itemsDocuments/2018-05-22_ref-palestine.pdf> (accessed 31 July 2018).

1592018 PE Report, supra n 16, at paras 251-284.

160 Ibid, at para. 282. 
examination as early as possible". ${ }^{161}$ However, it is silent as to whether the Prosecutor has determined that there is, or is not, a reasonable basis to believe that any crimes were committed, which is different to the other ongoing preliminary examinations where the OTP has proceeded to consider issues of admissibility.

On the issue of complementarity, the OTP noted that there is no evidence of national investigations or prosecutions in relation to settlement activity or other crimes in the West Bank and East Jerusalem but that there have been investigative activities in relation to alleged crimes perpetrated by the IDF in relation to the 2014 Gaza conflict. By contrast, it suggests that there are no ongoing national proceedings, in either Palestine or Israel, in relation to crimes allegedly committed by Palestinian armed groups. ${ }^{162}$

\section{Interests of Justice}

The final requirement of article 53(1) states that the Prosecutor should proceed to an investigation unless: "[t]aking into account the gravity of the crime and the interests of victims, there are nonetheless substantial reasons to believe that an investigation would not serve the interests of justice." To date the Prosecutor has never closed a preliminary examination on the basis of this "interests of justice" criteria. Furthermore, the OTP's analyses of this criteria tend to be very brief because article 53(1)(c) is framed in the negative, rather than something that the Prosecutor must establish. In September 2007, the OTP issued a Policy Paper on the Interests of Justice which emphasizes the exceptional nature of a decision by the Prosecutor not to proceed on this basis and that "there is a presumption in favour of investigation" when the criteria of jurisdiction and admissibility are satisfied. ${ }^{163}$ While the policy paper provides little guidance on what would satisfy this test, it distinguishes between the "interests of

\footnotetext{
161 Ibid, at para. 284.

162 Ibid at paras 277-279.

163 Supra note 39, at 1 \& 3.
} 
justice" and the "interests of peace", stating that the latter falls outside the purview of the OTP. ${ }^{164}$ In the intervening eleven years, the OTP has not reviewed this policy.

In most situations in which the OTP has concluded a preliminary examination with a decision to proceed to an investigation, very little is said about this criterion short of a brief sentence or two stating that there are "no reasons to believe that the opening of an investigation into the situation would not be in the interests of justice." 165 On some occasions, the OTP has pointed to support from victims and victim organisations for prosecutions to substantiate its conclusion to proceed. ${ }^{166}$ For example, in its preliminary examination in the situation in CAR I, the OTP noted, in particular, a recent mission to Bangui "where the OTP received clear confirmation that many of the victims in the Central African Republic were awaiting the involvement of the ICC in order to see justice done and to recover their dignity." 167 In its request for authorization of an investigation in the situation in Afghanistan, the OTP pointed to a nationwide consultation conducted by Afghanistan's Independent Human Rights Commission which "found that the desire for criminal justice was strong", as well as to a joint letter to the Prosecutor submitted by fifteen civil society organisations and an open letter published by 28 Afghan NGOs which both called on the ICC for action. ${ }^{168}$ Similarly, in concluding its preliminary examination in Georgia, the OTP pointed to submissions made by victims and human rights organizations indicating the victims' desire to see justice done, as well as the calls for an ICC investigation by the Office of the Public Defender/Ombudsman of Georgia. ${ }^{169}$ The OTP also noted

\footnotetext{
164 Ibid.

165 E.g., Côte d'Ivoire Request for Authorization, supra note 56, para. 60; Kenya Request for Authorization, supra note 52, at para. 61; Mali Article 53(1) Report, supra note 48, at para. 172; CAR II Article 53(1) Report, supra note 48, at para. 266.

166 ICC-OTP, Situation in Burundi, "Public redacted version of 'Request for authorisation of an investigation pursuant to article 15', 6 September 2017, ICC-01/17-5-US-Exp”, 5 November 2017, ICC-01/17-5-Red at paras 196-9 [Burundi Request for Authorization]. The OTP has said, in fact, that it has a policy to "consider, in particular, the interests of victims" in assessing this criterion. PE Policy Paper, supra note 33, at para. 68.

167 CAR Background, supra note 55.

168 Afghanistan Request for Authorization, supra note 68, at paras 364-372.

${ }^{169}$ Georgia Request for Authorization, supra note 52, at paras 339-44.
} 
that it considered "views expressed by the Parliamentary Assembly of the Council of Europe, which has recurrently called for independent investigations". ${ }^{170}$

\section{OUTCOMES OF PRELIMINARY EXAMINATIONS}

Once the OTP has concluded that all of the article 53(1) criteria are satisfied, the Rome Statute mandates that the Prosecutor shall open an investigation. If there was no referral by a state party or the Security Council, the Prosecutor must first obtain authorization from a Pre-Trial Chamber before the investigation can proceed. ${ }^{171}$ As of the 2018 report on preliminary examinations, twenty-seven preliminary examinations had been opened, twelve of which concluded with a decision to proceed to an investigation (seven under the leadership of Prosecutor Moreno-Ocampo ${ }^{172}$ and the remaining five during Prosecutor Bensouda's term). ${ }^{173}$ Of the remaining preliminary examinations, seven were closed with a decision not to proceed to an investigation (although the Iraq/UK preliminary examination was subsequently "re-opened") ${ }^{174}$ and nine (including Iraq/UK) remain ongoing. ${ }^{175}$

\footnotetext{
170 Ibid at para. 342.

171 Rome Statute, supra note 23, Article 15(3).

172 Namely: Uganda, DRC, Darfur, CAR I, Kenya, Libya, and Côte d'Ivoire.

173 Namely: Mali, CAR II, Georgia, Burundi, and Afghanistan.

174 The remaining six are: Venezuela I, South Korea, Palestine I, Honduras, Comoros, and Gabon.

${ }^{175}$ Namely: Bangladesh/Myanmar, the Philippines, Ukraine, Venezuela II, Colombia, Guinea, Iraq/UK, Nigeria, and Palestine.
} 
Fig 2: Outcome of preliminary examinations (as at 30 November 2018)

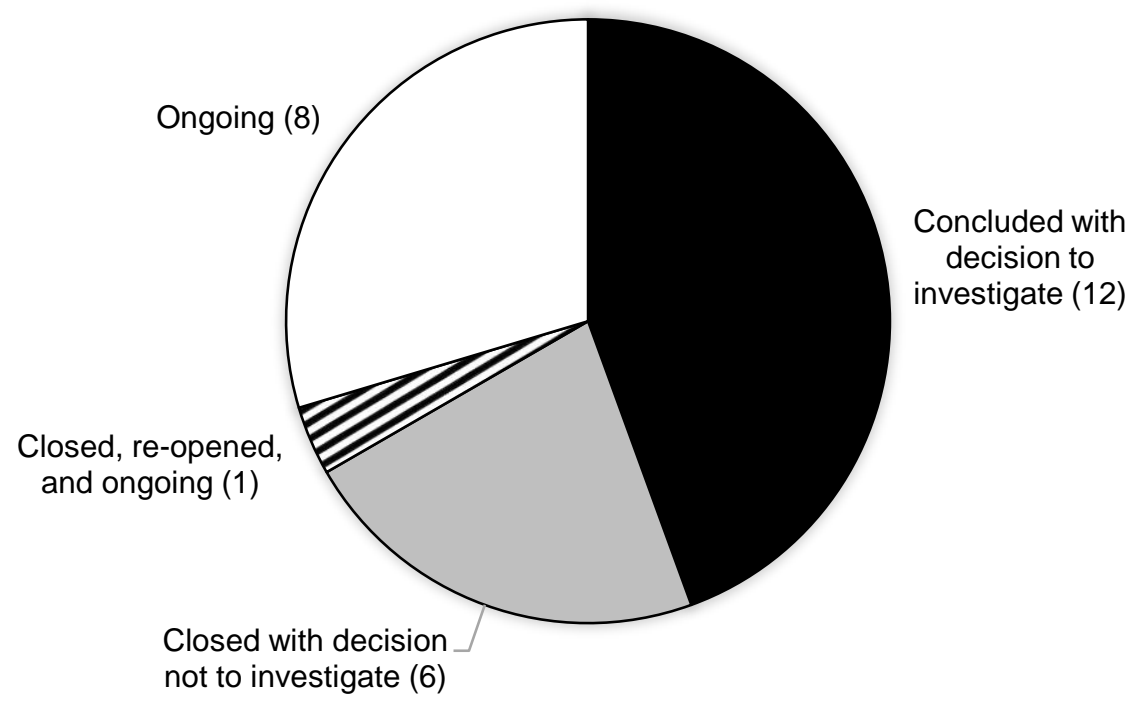

1. Preliminary Examinations Leading to an Investigation

The most common outcome for preliminary examinations has been to progress to an investigation. The first example was in June 2004, when Prosecutor Moreno-Ocampo opened an investigation in the DRC after receiving a 'self-referral' from that state in April 2004. ${ }^{176}$ Interestingly, although that investigation was triggered by a referral, the preliminary examination was opened by the Prosecutor on his own motion (in September 2003, the Prosecutor announced that he was ready to request authorization to open an investigation in the DRC, ${ }^{177}$ indicating that he had already conducted a preliminary examination proprio moto and determined that there was a reasonable basis to proceed). One month later, the Prosecutor opened a second investigation in the situation in Uganda. ${ }^{178}$ This

176 "Democratic Republic of the Congo", ICC Website online <https://www.icc-cpi.int/drc> (accessed 18 August 2018). 177 ICC-OTP, Press Release, "The Office of the Prosecutor of the International Criminal Court opens its first investigation", 23 June 2004, ICC-OTP-20040623-59, online: < https:/ /www.icc-

cpi.int/pages $/$ item.aspx? name $=$ the + office + of + the + prosecutor + of + the + international + criminal + court + opens + its + firs t+investigation $>$ (accessed 7 August 2018). ${ }^{178}$ ICC, Press Release, "ICC - Prosecutor of the International Criminal Court opens an investigation into Nothern [sic] Uganda”, 29 July 2004, online: <https://www.icc-

cpi.int/pages $/$ item.aspx?name $=$ prosecutor + of + the + international + criminal + court + opens + an + investigation + into + noth ern+uganda $>$ (accessed 26 November 2018).

${ }^{178}$ ICC, Press Release, "ICC - Prosecutor of the International Criminal Court opens an investigation into Nothern [sic] Uganda", 29 July 2004, online: <https://www.icc- 
development followed the decision by Ugandan President Yoweri Museveni to refer "the situation concerning the Lord's Resistance Army" - a rebel group which had been working to overthrow his government since the 1990 s - to the ICC Prosecutor in December 2003. ${ }^{179}$ Because the OTP did not announce the opening of preliminary examinations at this early stage in its practice, there is some uncertainty as to whether or not the Prosecutor was already conducting a preliminary examination into the Ugandan situation prior to Museveni's referral. ${ }^{180}$

For both the DRC and Uganda situation, there is limited information about the steps taken by the OTP during these early preliminary examinations. However, as time went on, the OTP's practice of opening preliminary examinations and investigations became increasingly transparent. On 22 May 2007, the OTP announced the start of a third investigation, this time into crimes allegedly committed in the CAR. ${ }^{181}$ This investigation followed a preliminary examination that began when the

cpi.int $/$ pages $/$ item.aspx?name $=$ prosecutor + of + the + international + criminal + court + opens + an + investigation + into + noth ern+uganda $>$ (accessed 26 November 2018).

${ }^{179}$ ICC, Press Release, "President of Uganda refers situation concerning the Lord's Resistance Army (LRA) to the ICC", 29 January 2004, ICC-20040129-44, online: <https://www.icc-

cpi.int/Pages $/$ item.aspx?name $=$ president + of + uganda + refers + situation + concerning + the + lord_s + resistance + army + lr a_+to+the+icc $>$ (accessed 31 December 2017).

${ }^{180}$ It is clear that the OTP was by no means a passive player in relation to the referral, but it is not clear that the OTP was actively analyzing the situation prior to receiving the referral. The language of its 2004 Press Releases suggests the referral triggered an analysis that would in substance amount to what are now called preliminary examinations.

Accordingly, we have categorized the situation in Uganda as having been triggered by a state referral. 29 January 2004 Press Release, ibid; ICC-OTP Press Release, "Prosecutor of the International Criminal Court opens an investigation into Northern Uganda”, 29 July 2004, ICC-OTP-20040729-65, available online: <https://www.icc-

cpi.int $/$ pages $/$ item.aspx? name $=$ prosecutor + of + the + international + criminal + court + opens + an + investigation + into + nort hern+uganda > (accessed 31 July 2018). It was not until later, in a 2008 speech at the London School of Economics that Prosecutor Moreno-Ocampo suggested that a preliminary examination was in effect completed before his office sought the referral from Uganda (in the same vein as in the situation in the DRC). Mr. Luis Moreno-Ocampo, Prosecutor, ICC, "The Tenth Anniversary of the ICC and Challenges for the Future: Implementing the Law", London, 8 October 2008 online <http://www.lse.ac.uk/humanRights/aboutUs/articlesAndTranscripts/ICClecture.pdf> (accessed 19 October 2018) at 6. See also David Bosco, Rough Justice (Oxford: Oxford University Press, 2014) at 97-98; Phil Clark, "Chasing Cases: The ICC and the Politics of State Referrals in the Democratic Republic of Congo and Uganda" in Carsten Stahn and Mohamed M. El Zeidy, eds, The International Criminal Court and Complementarity: From Theory to Practice (Cambridge: Cambridge University Press, 2011), 1188-1203; Sarah M.H. Nouwen and Wouter G. Werner, "Doing Justice to the Political: The International Criminal Court in Uganda and Sudan” (2010) 21:4 Eur J Intl L941.

181 ICC, "Prosecutor opens investigation in the Central African Republic", The Hague, 22 May 2007, online: $<$ https://www.icc-

cpi.int $/$ Pages $/$ item.aspx?name $=$ prosecutor + opens + investigation + in + the + central + african + republic $>($ accessed 18 August 2018). 
OTP received a self-referral from that state in December $2004^{182}$ and which took into account several communications from NGOs and international organizations, ${ }^{183}$ some of which were submitted before the referral was received. ${ }^{184}$

The next major development was in March 2005, when the UN Security Council referred the situation in Darfur, Sudan, to the ICC. ${ }^{185}$ Two months later, ${ }^{186}$ Prosecutor Moreno-Ocampo announced his decision to open an investigation into that situation. The Court's second UN Security Council referral came on 26 February 2011, in relation to the situation in Libya. Prosecutor MorenoOcampo announced the opening of the OTP's investigation into the situation a mere 5 days later, making this the shortest preliminary examination to date. ${ }^{187}$

After that flurry of referrals, the Prosecutor began to open investigations proprio motu. The first example concerned Kenya's 2007-2008 post-election violence. In line with the former Prosecutor's practice a of seeking referrals from states, the OTP held several discussions with Kenyan authorities about a possible state referral after beginning a preliminary examination in December 2007. ${ }^{188}$ However, no such referral eventuated and, in November 2009, the Prosecutor requested judicial authorization to open an investigation, and received that authorization in March 2010. ${ }^{189}$ In June 2011, the Prosecutor requested authorization to open another investigation proprio motu, this time in relation to the 2010-2011 post-election violence in Côte d'Ivoire. Côte d'Ivoire was at that time not a state party to the Rome Statute. However, it had accepted the jurisdiction of the Court through an article

\footnotetext{
182 Regarding the initiation of the CAR I preliminary examination, see CAR Background, supra note 55, at 1.

183 Ibid.

184 ICC-OTP, Situation in the Central African Republic, "Prosecution's Report Pursuant to Pre-Trial Chamber III's 30 November 2006 Decision Requesting Information on the Status of the Preliminary Examination in the Situation in the Central African Republic", 15 December 2006, ICC-01/05-7, at para. 13.

${ }^{185}$ First Al Bashir Arrest Warrant Decision, supra note 61, at para. 1.

186 On 1 June 2005. Ibid at para. 3.

${ }^{187}$ ICC, Situation in the Libyan Arab Jamabiriya, "Decision on the 'Prosecutor's Application Pursuant to Article 58 as to Muammar Mohammed Abu Minyar Gaddafi, Saif Al-Islam Gaddafi and Abdullah Al-Senussi”, p-T. Ch. I, 27 June 2011, ICC-01/11-01/11-1, at para. 2.

188 Ibid at para. 14.

${ }^{189} \mathrm{Ibid}$; ICC, Situation in Kenya, "Decision Pursuant to Article 15 of the Rome Statute on the Authorisation of an Investigation into the Situation in Kenya", p-T. Ch. II, 31 March 2010, ICC-01/09-19.
} 
12(3) declaration in $2003^{190}$ and later confirmed acceptance of the Court's jurisdiction on two further occasions. ${ }^{191}$ The pre-trial judges authorized the investigation on October $2011^{192}$ and, in February 2013, Côte d'Ivoire ratified the Rome Statute.

The ICC's next investigation, and the first opened by Prosecutor Bensouda, related to crimes allegedly committed in Mali. That investigation was opened in January 2013, after Bensouda received Mali's "self-referral” in July 2012 which triggered the preliminary examination. ${ }^{193}$ By November 2012, the OTP had already determined that there was a reasonable basis to believe that crimes within the jurisdiction of the Court had been committed, and the investigation was opened shortly thereafter. ${ }^{194}$ An earlier situation in the CAR had already been the subject of an investigation by the OTP when Prosecutor Bensouda opened an investigation in relation to a subsequent conflict in that state in September 2014 (CAR II). ${ }^{195}$ While the Prosecutor opened the CAR II preliminary examination proprio motu in February 2014, ${ }^{196}$ the CAR subsequently referred the situation to the Court on May 2014, removing the need to seek judicial authorization before the investigation could proceed. ${ }^{197}$

The investigation into the situation in Georgia, concerning the armed conflict in and around South Ossetia in 2008, was the next to be opened. This investigation was the first investigation opened

\footnotetext{
190 The OTP received the declaration on 1 October 2003, triggering the preliminary examination. Côte d'Ivoire Request for Authorization, supra note 56, at para. 15.

1912011 PE Report, supra note 141, at para. 120.

192 Côte d'Ivoire Request for Authorization, supra note 56; ICC, Situation in Côte d'Ivoire, "Decision Pursuant to Article 15 of the Rome Statute on the Authorization of an Investigation into the Situation in the Republic of Côte d'Ivoire", p-T. Ch. III, 3 October 2011, ICC-02/11-14.

193 ICC, "Renvoi de la situation au Mali", 13 July 2012, The Hague, online: <https://www.icccpi.int/NR/rdonlyres/A245A47F-BFD1-45B6-891C-3BCB5B173F57/0/ReferralLetterMali130712.pdf> (accessed 19 October 2018); Mali Article 53(1) Report, supra note 48, at paras 5, 15 \& 23-41.

1942012 PE Report, supra note 56, at, paras 142-170.195 ICC-OTP, "Statement of the International Criminal Court, Fatou Bensouda, on opening a second investigation in the Central African Republic", 24 September 2014, ICC-OTP20140924-PR1043, online: <https://www.icc-cpi.int/pages/item.aspx?name=pr1043> (accessed 9 September 2018). 195 ICC-OTP, "Statement of the International Criminal Court, Fatou Bensouda, on opening a second investigation in the Central African Republic", 24 September 2014, ICC-OTP-20140924-PR1043, online: <https://www.icccpi.int/pages $/$ item.aspx?name $=$ pr1043 $>$ (accessed 9 September 2018).

196 ICC-OTP, Press Release, "Statement of the Prosecutor of the International Criminal Court, Fatou Bensouda, on opening a new Preliminary Examination in Central African Republic", 7 August 2014, online: <https://www.icccpi.int/Pages/item.aspx?name=otp-statement-07-02-2014> (accessed 24 August 2018); CAR II Article 53(1) Report, supra note 48, Executive Summary, para. 4.

${ }^{197}$ CAR II Article 53(1) Report, supra note 48, at para. 5.
} 
in relation to a country outside of Africa, and the first investigation opened by Prosecutor Bensouda proprio motu. The preliminary examination was also notable, because unlike prior examples, it was initiated with the support of a major non-state party, Russia. In fact, the vast majority of article 15 communications that triggered the preliminary examination (a total of 3,817) were sent by the Prosecutor General of Moscow. ${ }^{198}$ The OTP commenced the preliminary examination on 14 August 2008 and, by 2011, concluded that there was a reasonable basis to believe that crimes within the jurisdiction of the Court were committed. ${ }^{199}$ On 17 March 2015, the Government of Georgia informed the OTP that national proceedings had been indefinitely suspended which prompted the OTP to conclude that "the potential cases identified in the Request would be admissible, due to State inaction." 200 The OTP requested authorization to open an investigation into the Situation in Georgia on 13 October 2015, which was granted by Pre-Trial Chamber I on 27 January $2016 .^{201}$

The commencement of the next investigation, in relation to the situation in Burundi, occurred in tense circumstances. On 25 April 2016, Prosecutor Bensouda announced that the OTP was opening a preliminary examination into crimes reportedly committed in Burundi since April 2015. ${ }^{202}$ In response to that announcement, Burundi submitted its notification of its intent to withdraw from the Rome Statute to the UN Secretary-General. ${ }^{203}$ Pursuant to article 127 of the Rome Statute, Burundi's withdrawal became effective one year later, making it the first state to officially withdraw from the Court. In the context of that impending deadline, the preliminary examination proceeded quicker than most. Despite not having reached a conclusion with respect to either questions of jurisdiction or

\footnotetext{
198 Report of the International Criminal Court to the Sixty-fourth session of the UN General Assembly, UNGOAR, A/64/356, 17 September 2009, at para. 48.

199 Georgia Request for Authorization, supra note 52, at paras 38-43.

2002015 PE Report, supra note 104, at paras 227 \& 255.

201 Georgia Request for Authorization, supra note 52; ICC, Situation in Georgia, "Decision on the Prosecutor's Request for authorisation of an investigation", p-T. Ch. I, 27 January 2016, ICC-01/15-12.

202 ICC-OTP, "Statement of the Prosecutor of the International Criminal Court, Fatou Bensouda, on opening a

Preliminary Examination into the Situation in Burundi”, 25 April 2016, online: <https://www.icccpi.int/Pages/item.aspx?name=otp-stat-25-04-2016> (accessed 18 August 2018).

2032017 PE Report, supra note 52, at para. 289.
} 
admissibility as of its 2016 preliminary examination report, ${ }^{204}$ by 17 August 2017 the Prosecutor had concluded her preliminary examination and notified the ICC President of her intent to submit a request for authorization, which was submitted on 6 September $2017 .{ }^{205}$ The Pre-Trial Chamber also moved quickly, granting authorization to open an investigation on 25 October $2017 .{ }^{206}$ The Prosecutor opened her investigation that same day, a mere two days before Burundi's withdrawal came into effect.

The most recent preliminary examination to conclude with a request for authorization to open an investigation is in the situation in Afghanistan. The OTP has stated that it has received article 15 communications in relation to Afghanistan since 1 June 2006. ${ }^{207}$ The Afghanistan preliminary examination, which relates to the conflict in and associated with that country following the $9 / 11$ attacks, ${ }^{208}$ is one of the longest known preliminary examinations to date, second only to Colombia (see Figure 5, below). ${ }^{209}$ By 2013, the OTP concluded that there was a reasonable basis to believe that crimes within the jurisdiction of the Court had been committed. ${ }^{210}$ However, it was not until 30 October 2017 that the Prosecutor notified the ICC President of her intent to submit a request for authorization of an investigation, which was submitted on 20 November $2017 .{ }^{211}$ In addition to numerous allegations against Taliban forces and "affiliated armed groups", as well as against Afghan National Security Forces, the OTP concluded that there is a reasonable basis to believe that members

2042016 PE Report, supra note 113, at para. 59 (current to 30 September 2016).

2052017 PE Report, supra note 52, at para. 283; Burundi Request for Authorization, supra note 166.

${ }^{206}$ ICC, Situation in Burundi, "Public Redacted Version of 'Decision Pursuant to Article 15 of the Rome Statute on the Authorisation of an Investigation into the Situation in Burundi', ICC-01/7-X-9-US-Exp, 25 October 2017”, p-T. Ch. III, 9 November 2017, ICC-01/17-9-Red.

2072011 PE Report, supra note 141, at para. 20.

2082017 PE Report, supra note 52, at paras 236-9.

${ }^{209}$ Kevin Jon Heller, “The OTP's Remarkable Slow-Walking of the Afghanistan Examination”, Opinio Juris (blog), 1 December 2013, online: <http://opiniojuris.org/2013/12/01/otps-remarkable-slow-walking-afghanistan-

examination/> (accessed 6 September 2018).

2102013 PE Report, supra note 81, at paras 35-52.

2112017 PE Report, supra note52, at para. 231; Afghanistan Request for Authorization, supra note 68. 
of the US armed forces and the CIA perpetrated crimes, ${ }^{212}$ making the situation in Afghanistan politically challenging given the US’s current posture towards the ICC.

\section{Preliminary Examinations Closed Without an Investigation}

As of 30 November 2018, seven preliminary examinations were closed with a decision not to proceed to an investigation The reasons for this outcome vary: As detailed above, one was closed because the OTP concluded that the preconditions to jurisdiction were not satisfied (Palestine I); four were closed because the OTP concluded that there were not reasonable grounds to believe that crimes within the ICC's jurisdiction had been committed (Venezuela I, South Korea, Honduras, and Gabon); and two were closed because the OTP concluded that the potential cases would be inadmissible due to insufficient gravity (Iraq/UK and Comoros).

In 2014, Prosecutor Bensouda “re-opened” the Iraq/UK preliminary examination - which the previous Prosecutor had closed for lack of gravity - on the basis of new information. ${ }^{213}$ Additionally, in relation to Comoros, Pre-Trial Chamber I for the first time ever requested the Prosecutor to "reconsider" her conclusion that the alleged crimes did not meet the gravity threshold for the ICC. ${ }^{214}$ While the Prosecutor affirmed her initial conclusion, judicial proceedings in relation to this situation remain ongoing. ${ }^{215}$ These two events suggest that conclusions based on gravity may be more susceptible to challenge, critique, or reconsideration given that the gravity threshold is highly discretionary and there is still a fair amount of debate about how it should be applied.

To date, no preliminary examinations have been closed due to the existence of genuine national proceedings (complementarity). However, when the OTP initially closed the Iraq/UK

\footnotetext{
212 Afghanistan Request for Authorization, supra note 68, at paras 187-252 \& 352-363. For a discussion of other international forces, see paras 253-260.

213 Prosecutor Re-Opens Preliminary Examination of the Situation in Iraq, supra note 66.

${ }^{214}$ Comoros Decision to Review, supra note 131.

215 See Part C(2), above.
} 
preliminary examination in 2006 on the basis of insufficient gravity, it also stated that "the Office also collected information on national proceedings $[\ldots]$ and that national proceedings have been initiated with respect to each of the relevant incidents." ${ }^{216}$ Recently, the OTP has reiterated that "the UK has initiated a number of criminal proceedings in relation to the conduct of UK troops in Iraq". ${ }^{217}$ Additionally, the OTP has been conducting some lengthy complementarity assessments, most notably in the situation in Colombia, as well as the Guinea and Nigeria preliminary examinations. Thus, one of these situations may become the first preliminary examination closed by reason of inadmissibility based on complementarity. Finally, the OTP has never concluded that it is not in the interests of justice to proceed to an investigation.

Figure 3: Reasons not to proceed past a preliminary examination (as at 30 November 2018)

\begin{tabular}{|l|c|c|c|c|c|}
\hline \multicolumn{2}{|c}{$\begin{array}{l}\text { Pre-conditions to } \\
\text { jurisdiction not } \\
\text { satisfied }\end{array}$} & $\begin{array}{l}\text { Jurisdiction } \\
\text { not satisfied }\end{array}$ & $\begin{array}{l}\text { Potential cases } \\
\text { inadmissible } \\
\text { (complementarity) }\end{array}$ & \multicolumn{2}{l|}{$\begin{array}{l}\text { Potential cases } \\
\text { inadmissible } \\
\text { (gravity) }\end{array}$} \\
\hline Venezuela I & & $\checkmark$ & & $\checkmark$ & \\
\hline Iraq/UK I & & & & & \\
\hline South Korea & & $\checkmark$ & & & \\
\hline Palestine I & $\checkmark$ & & & & \\
\hline Honduras & & $\checkmark$ & & & \\
\hline Comoros & & & & & \\
\hline Gabon & & $\checkmark$ & & & \\
\hline
\end{tabular}

\section{E. FREQUENCY AND DURATION}

The frequency with which preliminary examinations are opened has been fairly consistent, with one to three preliminary examinations opened or announced almost every year since the appointment of the Court's first prosecutor in June 2003.

\footnotetext{
216 Iraq Letter, supra note 59.

2172018 PE Report, supra note 16, at para. 200.
} 


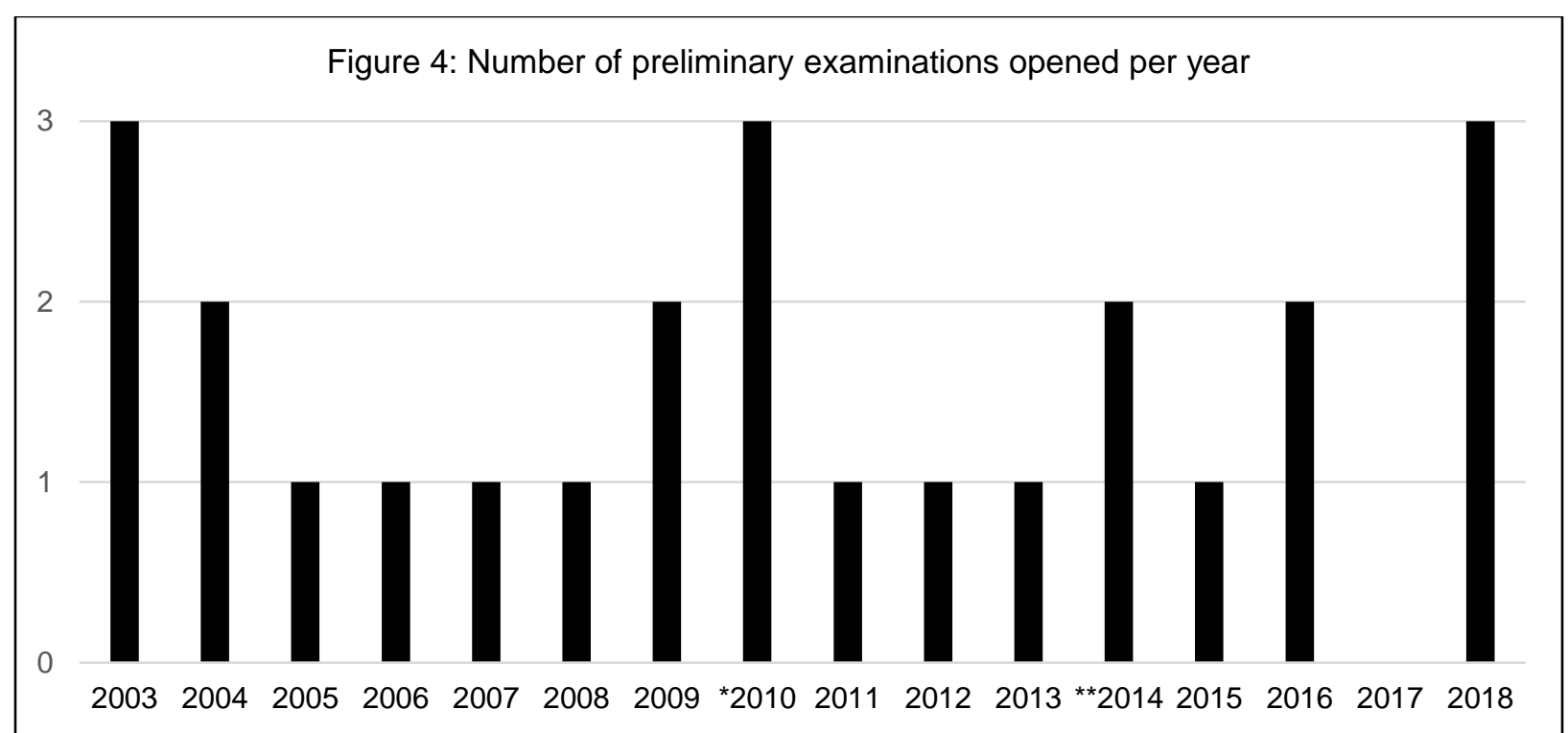

Not shown: Iraq/UK or Venezuela I (preliminary examinations closed in February 2006, but starting year unknown)

* Nigeria and Honduras preliminary examinations made public in 2010, but actual starting year unknown.

** Excludes Iraq/UK, which was 'reopened' in May 2014.

While there was a slight surge in the opening of preliminary examinations in the Court's early years, the frequency of new preliminary examinations has remained relatively consistent since then. It is noteworthy that there has been at least one new preliminary examination opened every year since the first Prosecutor took office, until 2017. However, 2017 was still a busy year for the OTP in relation to its preliminary examination activities, with the speedy conclusion of the Burundi preliminary examination, the request to open an investigation into Afghanistan being submitted, and the OTP's "final decision" on the Comoros preliminary examination being rendered. Furthermore, the fact that three new preliminary examinations have already been opened in 2018 demonstrates the continuing regularity of new preliminary examinations for the OTP. This consistency is interesting because it suggests that both state and non-state actors continue to turn to the ICC to seek justice for atrocities despite the criticisms that the Court has faced.

With respect to the duration of preliminary examinations, the OTP has stated that there are no "rigid timetables" for its work during the preliminary examination phase and that to impose such 
timetables "would not be workable". ${ }^{218}$ As multiple commentators have observed, the fact that the Prosecutor is under no time limitations to conduct preliminary examinations is legally correct. ${ }^{219}$ Reasons given by the Prosecutor for the absence of time limits include the need to monitor certain situations over time as they continue to develop, the potentially lengthy period of time needed to monitor national proceedings before making a decision on admissibility, and the prioritization necessarily resulting from the limited resources of the OTP. ${ }^{220}$

Despite the Prosecutor's stated objective “to complete all analyses as expeditiously as possible in order to reach timely decisions whether to investigate", 221 the OTP has been criticized for the relatively slow pace of some preliminary examinations. ${ }^{222}$ The sheer length of certain preliminary examinations has been criticized for keeping the potential accused, victims, and affected communities in "potential purgatory". ${ }^{223}$ Affected parties have raised similar concerns. For example, the legal team who submitted the referral on behalf of the state of Comoros sent multiple letters to the Prosecutor expressing concern about the length of time it was taking to make a decision about whether or not to proceed to an investigation. ${ }^{224}$ Similar concerns were expressed by the government of CAR after it submitted its first state referral to the Court. ${ }^{225}$ Chambers of the Court have also stressed the need for timeliness in the conduct of preliminary examinations. ${ }^{226}$ For example, in a recent decision relating to

\footnotetext{
218 Annex to 2003 Policy Paper, supra note17, at 3-4. The OTP has reiterated this on numerous occasions. E.g. 2017 PE Report, supra note 52 at para. 13; PE Policy Paper, supra note 33, at para. 89.

${ }^{219}$ Kersten, 'How Long', supra note 10; Pues, supra note 10. But see Pues at 445-7; ICC, Situation in the Central African Republic, "Decision Requesting Information on the Status of the Preliminary Examination of the Situation in the Central African Republic", p-T. Ch. III, 30 November 2006, ICC-01/05-6, at 4 [CAR Decision Requesting Information].

220 Annex to 2003 Policy Paper, supra note 17, at 3-4; PE Policy Paper, supra note 33, at para. 90.

221 Annex to 2003 Policy Paper, supra note 17, at 3.

222 Pues, supra note 10; Kersten, 'How Long', supra note 10; Human Rights Watch, ICC: Course Correction, 16 June 2011, online: <https://www.hrw.org/news/2011/06/16/icc-course-correction> (accessed 18 October 2017) [ICC: Course Correction]; Tillier, supra note 12, at 548-9.

223 Kersten, 'How Long', supra note 10_.

224 Comoros Application for Review, supra note 131, at paras 42-43.

${ }^{225}$ CAR Decision Requesting Information, supra note 219, at 2-3. See also Pavel Caban, "Preliminary Examinations by the Office of the Prosecutor of the International Criminal Court" (2011) 2 Czech Yearbook of Public \& Private International Law 199, at 211; Pues, supra note 10, at 442-43.

226 PTC Decision regarding Myanmar and Bangladesh, supra note 121, at paras 83-88.
} 
the Bangladesh/Myanmar situation, Pre-Trial Chamber I stated that "[e]xtended preliminary examinations affect the rights of victims and maintain them in a state of uncertainty which is prejudicial." ${ }^{227}$

The disparity in length among preliminary examinations has also been criticized for "feed[ing] into the perceptions of bias with which the Court is struggling." 228 Finally, it has also been suggested that allowing preliminary examinations to go on for so long may work against the Court's deterrent efforts by "desensitizing actors". 229

In response to such criticisms, many have suggested the imposition of timelines for preliminary examinations and increased judicial review of prosecutorial activities if the office fails to proceed within such timelines. ${ }^{230}$ While some of the strict timelines suggested by these authors may be untenable for the OTP, the unduly lengthy nature of some preliminary examinations, as well as the vastly disparate lengths amongst preliminary examinations, have justifiably raised concerns.

${ }^{227}$ Comoros Decision on Application for Judicial Review, supra note 134, at para. 120.

${ }^{228}$ Pues, supra note 10 at 436.

${ }^{229}$ Ibid at 437.

${ }^{230}$ Ibid at 452-53; Grotius Centre Report, supra note 6, at paras 14-17; Human Rights Watch, 'ICC: Course Correction', supra note 222. 


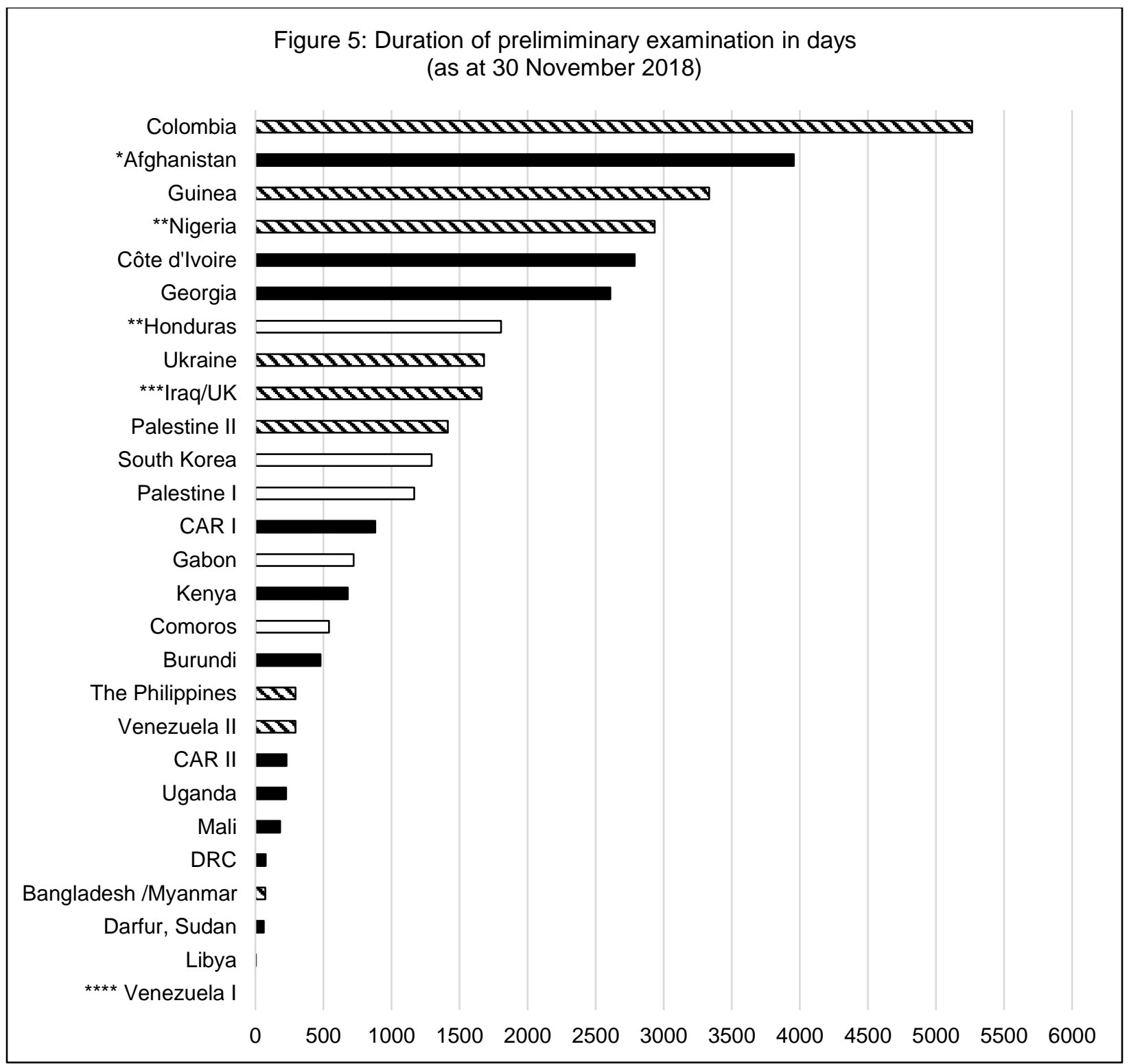

Black bars represent preliminary examinations that concluded with an investigation; white bars represent preliminary examinations that closed without an investigation; striped bars represent ongoing preliminary examinations.

* Afghanistan preliminary examination has been open "since 2006" but specific start date unknown (thus, the last date of that year used for purposes of calculation).

** Nigeria and Honduras preliminary examinations made public on 18 November 2010 but actual start dates unknown.

*** No initial start date for Iraq/UK preliminary examination is available. Start date for calculation above is the date on which the preliminary examination was "re-opened".

**** Venezuela I preliminary examination closed in 2006 but start date unknown. Therefore, there is no basis to calculate duration. 
Figure 5 shows the duration of preliminary examinations based upon the best publically available information. ${ }^{231}$ As is immediately apparent, the length of different preliminary examinations varies drastically. The preliminary examination in Libya lasted only five days before the OTP decided to proceed to an investigation, whereas the preliminary examination in Colombia has been ongoing for more than fourteen years. The longest concluded preliminary examination involves the situation in Afghanistan which lasted well over ten years at least.

The OTP has demonstrated that preliminary examinations can be completed in a timely fashion, with half a dozen being completed in less than a year and a total of ten preliminary examinations completed in less than two years. On the other hand, another half a dozen preliminary examinations have lasted more than seven years, including the situations in Nigeria, Georgia, Côte d'Ivoire, Guinea, Afghanistan, and Colombia, with three of these still ongoing. Eighteen preliminary examinations have been completed to date with an average length of just over 1041 days (2.85 years). ${ }^{232}$

It has been suggested that preliminary examinations that entail very involved complementarity assessments will be lengthier as the OTP engages with the state to evaluate the status of domestic proceedings. ${ }^{233}$ Examples include the ongoing preliminary examinations in Nigeria, Guinea, and Colombia, which have been at the admissibility phase for approximately five years, seven years, and eight years respectively thus far. On the other hand, there have been lengthy preliminary examinations where the bulk of time was spent determining whether or not there is a reasonable basis to believe that the Court has subject-matter jurisdiction. For example, the preliminary examination in Côte d'Ivoire was opened on 1 October 2003. ${ }^{234}$ In his December 2010 address to the ASP, Prosecutor Moreno-Ocampo stated that "the Office is examining whether crimes under the jurisdiction of the

\footnotetext{
231 See Section III above for discussion of how these durations were calculated.

232 The Venezuela I preliminary examination is not included in this calculation since there is no information on when it was opened and, thus, no way to calculate its duration.

233 Grotius Centre Report, supra note 6, at para. 18; Pues, supra note 10 at 440-41; Stahn, supra note 9, at 428.

234 Côte d'Ivoire Request for Authorization, supra note 56, at para. 15.
} 
Court exist" in the preliminary examination in Côte d'Ivoire, indicating that the OTP was still at the phase II assessment this late in the preliminary examination. ${ }^{235}$ And yet, the preliminary examination was concluded five-and-a-half months later when the Prosecutor informed the President of his intention to submit a request for authorization of an investigation. ${ }^{236}$ Thus, the bulk of the over sevenand-a-half year long preliminary examination was spent determining the question of jurisdiction. By contrast, the rather quick complementarity assessment was made upon receipt of a letter to the Prosecutor from President Ouattara stating that " "the Ivorian judiciary is not at this stage in the best position to address the most serious of the crimes' committed since 28 November 2010, and 'any attempt at trying the most responsible individuals may face multiple obstacles'.,237

\section{F. GEOGRAPHY}

One of the strongest and most consistent points of critique of the ICC is the perceived bias of the Court with respect to African states. Assessing whether such bias exists would require a comprehensive comparison against unprosecuted grave crimes within the Court's jurisdiction, which is beyond the scope of this paper. However, a geographical assessment of the content of the OTP's preliminary examinations helps to nuance this critique and is also informative, because it provides a fuller picture of where the OTP has focused its efforts, and where it may be operating in the future.

First, it is clear that the Court's first twenty-seven preliminary examinations have primarily concerned conflict and mass violence in African states (Figure 6). Of the twenty-seven preliminary examinations that had been opened as at 30 November 2018: thirteen have concerned crimes allegedly

\footnotetext{
235 Mr. Luis Moreno-Ocampo, “Address to the Assembly of States Parties", Ninth Session of the Assembly of States Parties, The Hague, 6 December 2010, online: <https://asp.icc-cpi.int/iccdocs/asp_docs/ASP9/Statements/ICC-ASP9statements-LuisMorenoOcampo-ENG.pdf $>$ (accessed 21 October 2018) at 5.

${ }^{236}$ Côte d'Ivoire Request for Authorization, supra note 56, at para. 8.

${ }^{237}$ Ibid at para. 49.
} 
committed solely in African states; ${ }^{238}$ four have concerned crimes allegedly committed solely in Latin American and Caribbean states; ${ }^{239}$ five have concerned crimes allegedly committed solely in AsiaPacific states ${ }^{240}$ two have concerned crimes allegedly committed solely in Eastern European states; $;^{241}$ one concerned crimes allegedly committed in both Asia-Pacific and Eastern European states; $;^{242}$ one concerns crimes allegedly committed in both an Asia-Pacific and a state from the 'Western European and Others Group' (WEOG); ${ }^{243}$ and one involves an African state, an Asian-Pacific state, and a WEOG state. ${ }^{244}$ Based on the location of the alleged crimes, this brings the total number of preliminary examinations for each geographic region to: Africa (14), Asia-Pacific (8), Latin America and Caribbean (4), Eastern Europe (3), and WEOG (2).

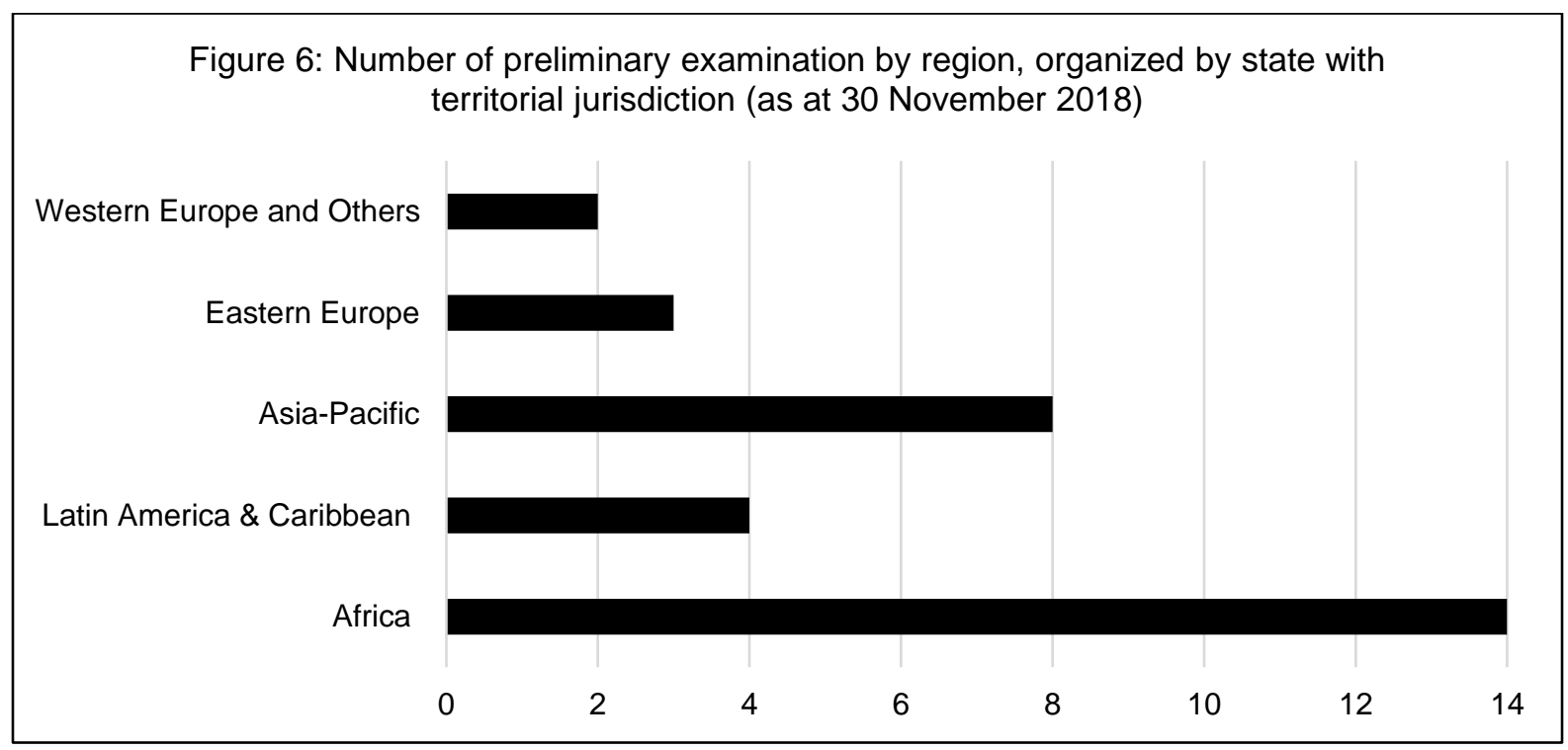

\footnotetext{
238 Burundi, CAR I, CAR II, Côte d'Ivoire, Darfur, DRC, Gabon, Guinea, Kenya, Libya, Mali, Nigeria, Uganda.

${ }^{239}$ Colombia, Honduras, Venezuela I, and Venezuela II.

240 Bangladesh/Myanmar, Iraq/UK, Palestine I, South Korea, and the Philippines.

241 Georgia, and Ukraine

${ }^{242}$ In the 'Afghanistan' preliminary examination, the OTP analyzed crimes allegedly committed in Afghanistan, Poland, Lithuania, and Romania.

243 In the 'Palestine II' preliminary examination, the OTP is analyzing crimes allegedly committed in Palestine and Israel, including rocket and mortar attacks allegedly launched from Palestine into Israel's territory See 2016 Preliminary Examination Report, para. 123.

${ }^{244}$ In the 'Comoros' preliminary examination, the OTP analyzed crimes allegedly committed on vessels registered to Comoros, Cambodia, and Greece.
} 
To better understand the geographic spread of preliminary examinations, it is also relevant to consider the states of nationality of the alleged perpetrators (Figure 7 ). ${ }^{245}$ Thirteen preliminary examinations concern crimes allegedly committed by African nationals, once again making Africa the most represented region by a significant margin. Furthermore, the same four preliminary examinations that concern crimes allegedly committed in Latin America and Caribbean states also involve potential allegations against nationals from those same states.

From there, the picture begins to change and the role of non-states parties becomes more visible. The number of preliminary examinations concerning WEOG states climbs from two to four (because the Palestine II and Comoros preliminary examinations both involve allegations against Israeli nationals, the Afghanistan preliminary examination involves allegations against nationals from the U.S., and the Iraq/UK preliminary examination involves allegations against UK nationals). The number of preliminary examinations concerning Asia-Pacific states drops from eight to five (the preliminary examination in South Korea involves allegations against North Koreans, the Philippines preliminary examinations involves allegations against nationals of that state, the Bangladesh/Myanmar preliminary examination involves allegations against nationals of Myanmar, and both the Palestine II and Afghanistan preliminary examinations involve allegations against nationals of those two states). ${ }^{246}$ And the number of preliminary examinations concerning Eastern Europe drops from three to two, namely the Georgia preliminary examination (which included allegations against Georgian nationals

\footnotetext{
${ }^{245}$ No information about alleged perpetrators is available in relation to the Palestine I preliminary examination.

246 This drop also reflects the fact that the Palestine I preliminary examination was counted for the purposes of assessing territorial jurisdiction but is excluded for the purposes of counting the states of nationality jurisdiction as no explicit information was given in that preliminary examination with respect to potential perpetrators.
} 
and members of the Russian armed forces) and the Ukraine preliminary examination (which includes allegations against Ukrainian and members of the Russian armed forces). ${ }^{247}$

Thus, the OTP has analyzed, or is currently analyzing, allegations against three permanent members of the UN Security Council (U.S., U.K., and Russia), as well as Israel, another powerful nonparty state (Russia and the U.S. are similarly not party to the ICC). This picture also reveals that the OTP has been more active in relation to WEOG states than much of the public commentary of the Court suggests, at least at the preliminary examination stage.

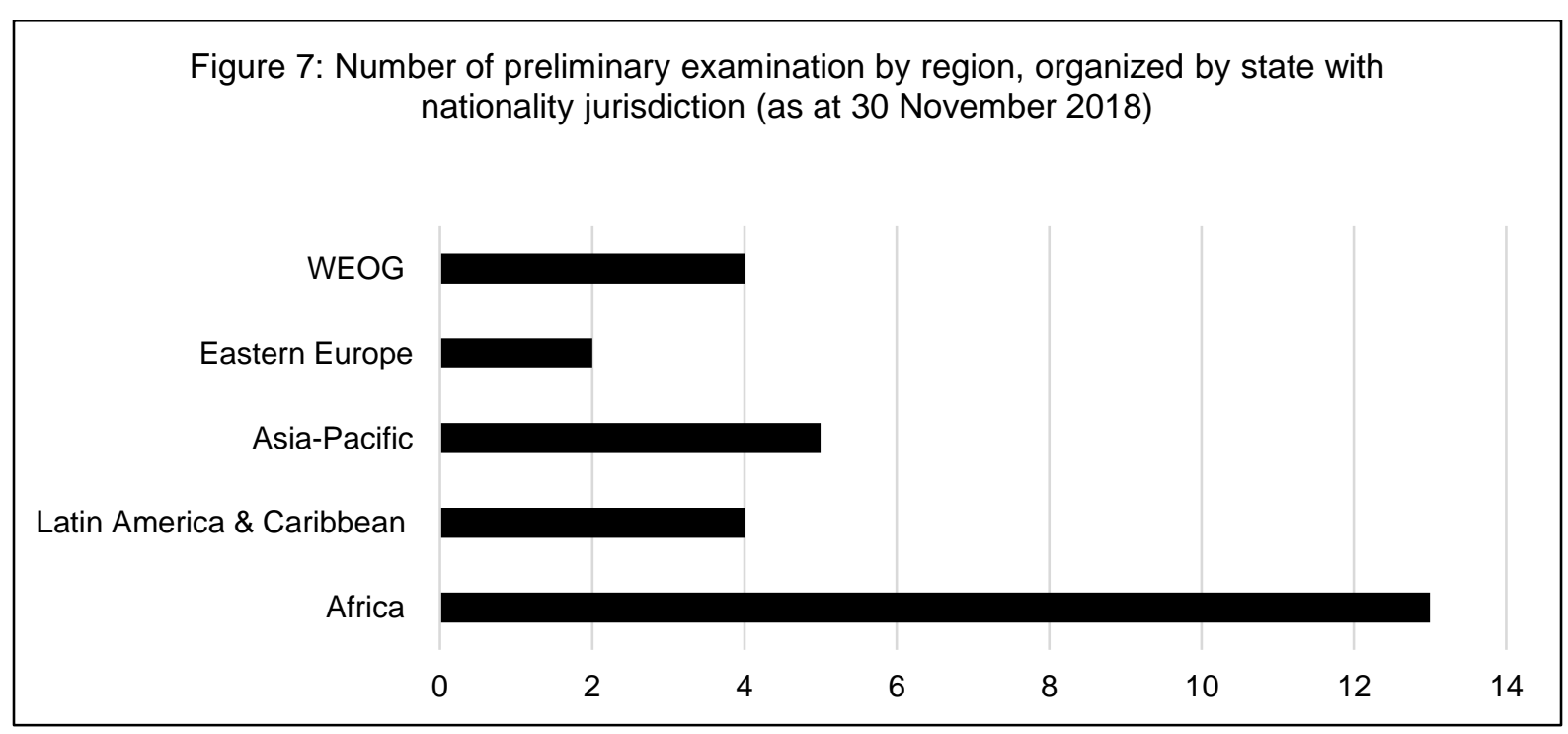

Of course, the OTP's preliminary examination work is only one piece of the Court's overall work and most victims, perpetrators, and those evaluating and critiquing the Court will be more concerned with the actual investigations and prosecutions and the territories in relation to which they do or do not occur. It is beyond dispute that the OTP's early investigations and prosecutions are heavily dominated by African states, with the first nine investigations opened relating to African nations. It was not until 2016 that the first preliminary examination proceeded to the opening of an

247 Georgia Request for Authorization, supra note 52, at para. 2; 2017 PE Report, supra note 52, at paras 96-110. Note: In relation to Georgia, the OTP concluded that there was insufficient information to find a reasonable basis to believe that crimes were committed by members of the Russian armed forces. See Georgia Request for Authorization, Georgia Request for Authorization, supra note 52, at paras 208-211. 
investigation in relation to a non-African state in the situation in Georgia. This was followed, again, by an African state in the situation in Burundi. Most recently, reaching out of the African continent once more, the OTP has requested authorization to open an investigation in relation to the situation in Afghanistan. Nonetheless, a deeper look at all preliminary examinations helps to give a fuller picture of how the Court got to this place and also some indication of where it may be heading.

Of the preliminary examinations that were closed with a decision not to proceed to an investigation, these include two in which the alleged crimes occurred in the Latin America and Caribbean region (Venezuela I and Honduras), two in which the alleged crimes occurred in the AsiaPacific region (South Korea and Palestine I), one in which the alleged crimes occurred in Africa (Gabon), and one in relation to crimes allegedly perpetrated on vessels from Africa, Asia, and WEOG, by WEOG (Israeli) nationals in the situation in Comoros. Finally, the preliminary examination involving allegations against WEOG nationals (UK) on the territory of an Asia-Pacific state (Iraq) was initially closed but subsequently re-opened.

Of the current ongoing preliminary examinations: two relate to crimes allegedly committed in African states and by nationals of those states (Guinea and Nigeria); two relate to crimes allegedly committed in Latin American states and by nationals of those states (Colombia, Venezuela II); one relates to crimes allegedly committed in Eastern Europe, by nationals of Eastern European states (Ukraine); two relate to crimes allegedly committed exclusively in Asia-Pacific states and by nationals of Asia-Pacific states (the Philippines and Bangladesh/Myanmar); one relating to nationals and the territory of both Asia-Pacific and WEOG (Palestine II); and the preliminary examination into crimes committed by WEOG nationals (UK) on Asia-Pacific (Iraq) territory has been "re-opened". Thus, there is the potential for the Court to move in the direction of a somewhat more geographically diverse future of investigations and prosecutions with the Asia-Pacific region being the most prevalent region for ICC investigations on the horizon. 


\section{G. CORRELATIONS}

Thus far, we have presented findings based on individual criteria. However, when one considers correlations across several criteria, a more detailed picture emerges.

\section{Triggers and Outcomes}

For example, by considering the trigger and outcomes together, we can better assess the role that states, the Security Council, and other actors play in triggering the actions of the ICC (see Figure 8). ${ }^{248}$

Fig 8: Triggers \& outcomes for ICC preliminary examinations (as at 30 November 2018)

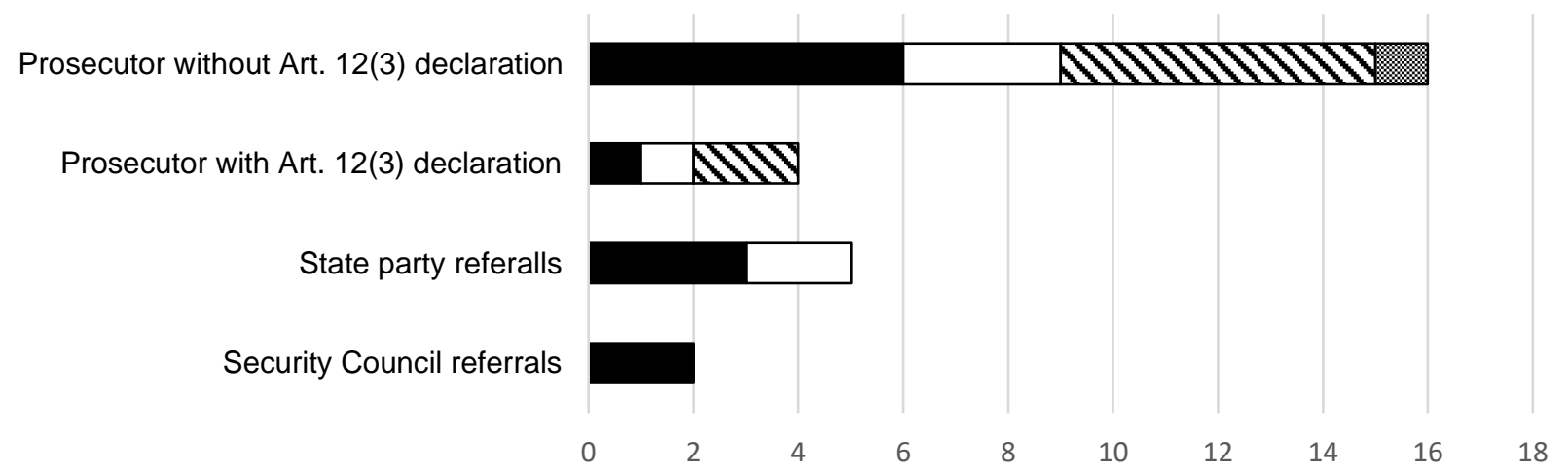

- Concluded with decision to investigate $\square$ Closed with decision not to investigate vOngoing 圆Closed, "re-opened", and ongoing

Both preliminary examinations triggered by Security Council resolutions resulted in the opening of investigations and, ultimately, the issuance of arrest warrants. Three of the five preliminary examinations triggered by state referrals also resulted in investigations being opened and arrest warrants being issued, the exceptions being the situations in Comoros and Gabon. The outcomes of

\footnotetext{
248 See David Bosco, “Discretion and State Influence at the International Criminal Court: The Prosecutor's Preliminary
} Examinations" (2017) 111:2 AJIL 395. 
the preliminary examinations opened proprio motu have been far more varied. Of the four preliminary examinations initiated by the Prosecutor proprio motu upon receipt of an article 12(3) declaration, one proceeded to investigation (Côte d'Ivoire), one was closed without an investigation (Palestine I), and two are ongoing (Ukraine and Palestine II). Outcomes also vary significantly among preliminary examination opened proprio motu without an article 12(3) declaration. Three of these preliminary examinations were closed due to lack of subject-matter jurisdiction (Venezuela I, Honduras, and South Korea), a fourth was closed due to insufficient gravity but subsequently re-opened (Iraq/UK), six remain continuously ongoing (Bangladesh/Myanmar, Colombia, Guinea, Nigeria, the Philippines, and Venezuela II), and six have led to an investigation or a request to authorize an investigation (Afghanistan, Burundi, CAR II, DRC, Georgia, and Kenya).

With respect to the preliminary examinations that concluded (whether with an investigation or with a decision not to proceed), a pattern in outcome has begun to emerge based on whether or not the trigger involved explicit consent of one or more states. ${ }^{249}$ To explain, both preliminary examinations triggered by the Security Council resulted in the opening of an investigation. Additionally, of the eight other situations in which the state in some way invited the Prosecutor to act (either by a state self-referral, an article 12(3) declaration, or a post hoc self-referral which indicates state consent after a preliminary examination was opened, even if it was not present initially), six (75\%) resulted with a decision to proceed to an investigation. ${ }^{250}$

\footnotetext{
${ }^{249}$ By the term "explicit" state consent we seek to distinguish the situation of the state consent denoted by ratification of the Rome Statute in the first place.

250 These six are: Uganda, CAR I, Mali (in which the preliminary examination was triggered by a state party referral); Côte d'Ivoire (in which the preliminary examination was triggered in response to an Article 12(3) declaration); and the DRC and CAR II (in which the Prosecutor received a post hoc state party referral after initiating a preliminary examination). The remaining two preliminary examinations which involved explicit state consent, but which were closed without an investigation, are Comoros and Gabon. For the purposes of this analysis, the decision not to proceed in relation to the Palestine I preliminary examination is excluded because its attempted article 12(3) declaration was found to be invalid because there was no clear confirmation from the UN General Assembly of the statehood of Palestine at that time and, accordingly, it would be inaccurate to classify this as a situation involving "state" consent.
} 
By contrast, of the concluded preliminary examinations that were triggered by the Prosecutor without explicit state consent, four have concluded with a decision to proceed to an investigation ${ }^{251}$ and three were closed due to lack of subject matter jurisdiction. ${ }^{252}$ Thus, of the seven concluded preliminary examinations in this category, $57 \%$ resulted in a decision to proceed to an investigation. This discrepancy suggests that explicit state consent tends to somewhat increase the likelihood that the Prosecutor will seek authorization to proceed to an investigation.

\section{Triggers and Frequency}

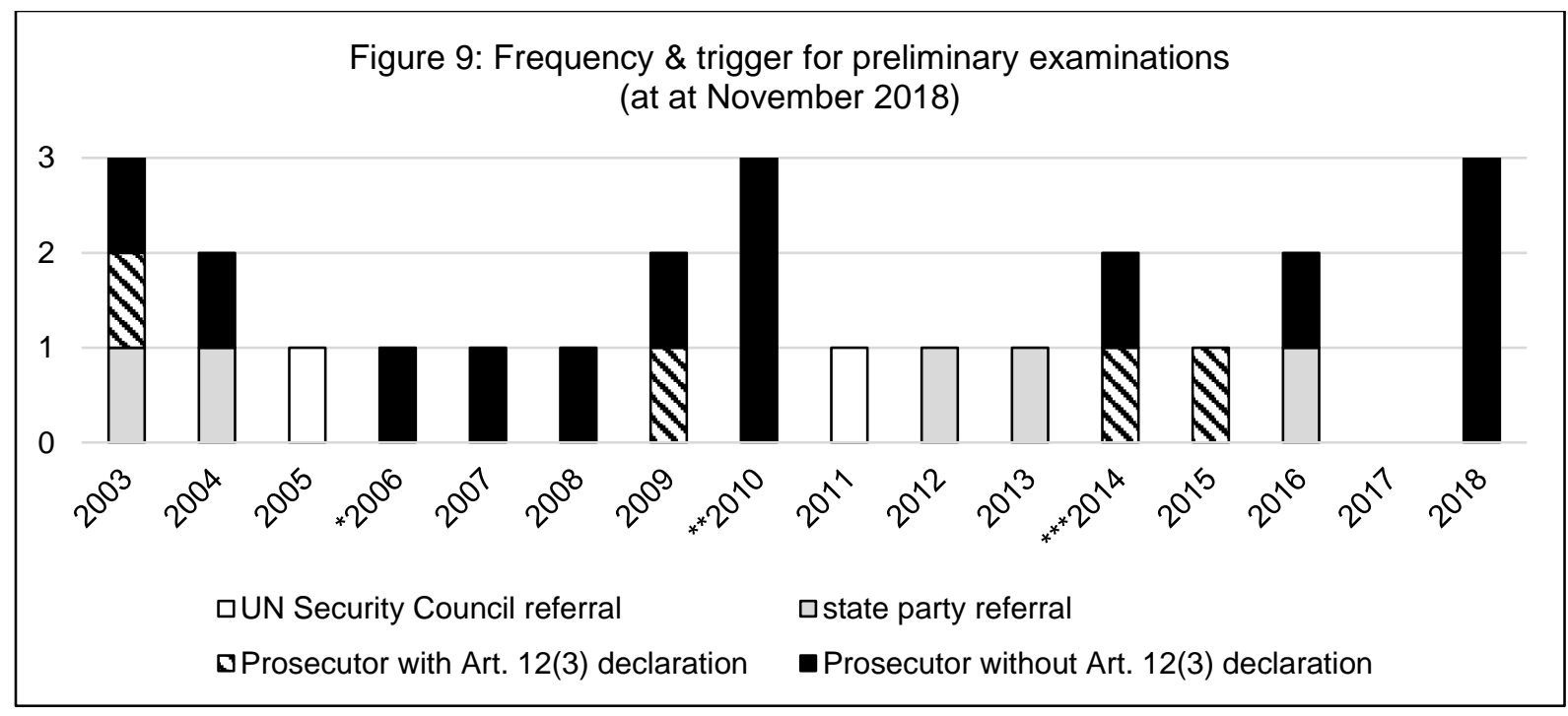

* Iraq/UK and Venezuela I preliminary examinations closed in February 2006 but starting year unknown.

** Nigeria and Honduras preliminary examinations made public in 2010 but actual starting dates unknown.

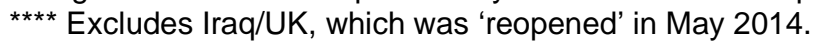

As there have only been two Security Council referrals, not much can be said about their frequency.

However, it is noteworthy that, despite the fact that neither referrals has resulted in a case that has

251 Namely: Kenya, Afghanistan, Georgia, and Burundi

252 Namely: Venezuela I, South Korea, and Honduras. 
proceeded smoothly to trial, ${ }^{253}$ attempts have still been made to have further Security Council referrals (for example, in relation to Syria ${ }^{254}$ and Myanmar $^{255}$ ).

With respect to state referrals, there were a couple of referrals early on in the Court's practice, followed by a lull in the receipt of state party referrals for a number of years between 2004 and 2012 . This is even more apparent if one combines both the triggering state party referrals and the four post hoc referrals which occurred in 2004, 2014, and two in $2018 .{ }^{256}$ This gap may represent some hesitancy on the part of states after the initial burst of referrals to see how the Court's work progressed as it actually began its first prosecutions, although there is no way to know for sure. It may also simply reflect the fact that the Prosecutor stopped being so active in seeking referrals. It is interesting, however, that the frequency of state party referrals has picked up again in recent years. This suggests that, despite the many criticisms levied at the Court, states are still willing to turn to the ICC. It is particularly noteworthy that of the six referrals submitted since 2012 (including post hoc referrals), four have come from African countries ${ }^{257}$ despite the general AU position of antipathy towards the Court, including threats of mass withdrawals. ${ }^{258}$ A somewhat similar pattern is apparent with article 12(3) declarations, with somewhat of a gap appearing after the Court's initial years but with continuing use of this mechanism more recently as exhibited by the declarations submitted by Ukraine in 2014 and Palestine in 2015.

\footnotetext{
${ }^{253}$ See, e.g., Mark Kersten, “Buyer's Beware - Is a UN Security Council Referral of Myanmar to the International Criminal Court a Good Idea" (31 August 2018) Justice in Conflict (blog), online:

<https://justiceinconflict.org/2018/08/31/buyers-beware-is-a-un-security-council-referral-of-myanmar-to-theinternational-criminal-court-a-good-idea/> (accessed 31 August 2018).

${ }^{254}$ UN Press Release, "Referral of Syria to International Criminal Court Fails as Negative Votes Prevent Security Council from Adopting Draft Resolution”, 22 May 2014, available online: <https://www.un.org/press/en/2014/sc11407.doc.htm> (accessed 18 August 2018).

255 E.g., Human Rights Watch, "UN Security Council: Refer Myanmar to ICC”, 18 May 2018, online: <https://www.hrw.org/news/2018/05/08/un-security-council-refer-myanmar-icc> (accessed 18 August 2018). 256 We refer to the DRC's post hoc referral in April 2004; the CAR's second self-referral in May 2014, Palestine's post hoc referral in May 2018, and the joint post hoc referral of Venezuela II in September 2018.

257 Mali, Comoros, Gabon, and CAR.

258 See, e.g., BBC News, “African Union backs mass withdrawal from ICC”, 1 February 2017, online:

<https://www.bbc.com/news/world-africa-38826073> (accessed 18 August 2018).
} 
With respect to preliminary examinations opened by the Prosecutor without article 12(3) declarations, the frequency pattern is different. After fairly consistent frequency of new preliminary examinations proprio motu in the Court's early years and a spike in 2010, the frequency of such preliminary examinations tapered off for a number of years. This is not a reflection of a change in the submission of article 15 communications which has remained relatively consistent and have continued to come in high volumes each year. ${ }^{259}$ More likely, it is a question of resourcing: given that the OTP must work within a budget and cannot control when the next referral will come, there is a practical incentive for the Prosecutor to take a conservative approach to opening preliminary examinations proprio motu. Having said that, the instigation of three new preliminary examinations on this basis in 2018 indicates that the OTP remains responsive to reported crimes, even in the face of resource constraints.

\section{Triggers and Geography}

Considering the trigger when compared to the geography of different preliminary examinations is revealing and helps nuance some of the critiques of the court such as the alleged African bias. It is well known that the two Security Council referrals involve African states and that such referrals have been unsuccessful in relation to non-African countries. However, it is also noteworthy that all five preliminary examinations triggered by state party self-referrals concern crimes allegedly perpetrated in African states or on an African-flagged vessel, ${ }^{260}$ as did one of the preliminary examinations initiated in response to an Article 12(3) declaration (Côte d'Ivoire) and two preliminary examinations in which the states concerned made post hoc referrals (the DRC and CAR II). Thus, when one looks at the triggers for preliminary examinations and investigations together, it is clear that many

\footnotetext{
${ }^{259}$ Grey and Wharton, supra note 5.

${ }^{260}$ Namely: Uganda, CAR I, Mali, Comoros and Gabon. The Comoros referral involves allegations against Israeli nationals and also potentially including the vessels registered to Cambodia and Greece.
} 
African states have come have "invited in" ICC activity, so to speak (although sometimes, in the early days, at the prompting of the Prosecutor). ${ }^{261}$ This state-led activity, together with the approach of the UN Security Council, has contributed to the ICC's initials focus on the African continent.

The OTP has played an important part in expanding the Court's reach beyond Africa. Of the preliminary examinations triggered proprio motu without an article 12(3) declaration, six concern crimes allegedly committed in African states, ${ }^{262}$ four concern crimes committed in Latin America, ${ }^{263}$ two concern crimes committed in Eastern Europe, ${ }^{264}$ and five concern crimes committed in Asia-Pacific. ${ }^{265}$ Additionally, two of these preliminary examinations involve allegations against nationals from two WEOG states, namely the US and UK. ${ }^{266}$

\section{Geography and Duration}

We also looked at the geography of preliminary examinations in relation to their duration. As noted above, both Security Council referrals were the two shortest preliminary examinations and both relate solely to African countries. This trend is repeated when looking at the four other preliminary examinations completed in less than a year which, again, include only African countries (DRC, Uganda, Mali, and CAR II). The Burundi, Kenya, Gabon and CAR I preliminary examinations were also relatively short, all concluding in less than two and a half years. The only other preliminary examination completed in less than two years was the situation in Comoros, involving allegations against Israeli nationals, which lasted just under a year and a half (although proceedings in relation to this preliminary examination were subsequently prolonged due to the request for reconsideration). In

\footnotetext{
261 See notes 177 and 180, above.

${ }^{262}$ Namely: DRC, Kenya, Guinea, Nigeria, CAR II, and Burundi.

263 Namely: Venezuela I, Colombia, Honduras, and Venezuela II.

264 Namely: Georgia, and Afghanistan (which includes crimes allegedly committed by members of the CIA in Poland, Lithuania, and Romania).

265 Namely: Afghanistan, Iraq/UK, Republic of Korea, the Philippines, and Bangladesh/Myanmar.

266 These two preliminary examinations are Afghanistan and Iraq/UK, respectively.
} 
fact, including the Comoros preliminary examination (in which crimes were alleged to have been perpetrated on the territory of an African flagged vessel although allegations were against non-African nationals), the eleven shortest concluded preliminary examinations all involved African countries. The six completed preliminary examinations that took longest to conclude are more geographically diverse, including Palestine I, South Korea, Honduras, Georgia, Côte d'Ivoire, and Afghanistan. While there are many reasons why the Prosecutor may proceed quickly or slowly in any given preliminary examination, this paints an interesting picture in relation to critiques about the Court's willingness to act in Africa as well as concerns about the prolonged wait for justice by victims in other regions. Thus, the Prosecutor would do well to explain why the OTP proceeded so quickly in some preliminary examinations and far more slowly in others.

\section{Triggers and Duration}

As has been observed elsewhere, the length of preliminary examinations vary with respect to the jurisdictional trigger. ${ }^{267}$ In particular, the two preliminary examinations triggered by UN Security Council referral are the shortest of all preliminary examinations. State party referrals clearly represent the second shortest category. The longest preliminary examination triggered by a state party referral is the situation in CAR I, which lasted for two years and five months, and all preliminary examinations triggered by state party referrals (which are all now concluded) lasted less than the average total length of 2.85 years. Preliminary examinations triggered by article 12(3) declaration are generally lengthier, despite the fact that they also involve states inviting ICC intervention. The Palestine I preliminary examination took over three years to conclude that the declaration was invalid and, as mentioned above, the Côte d'Ivoire preliminary examination lasted close to eight years.

${ }^{267}$ Pues, supra note 10 at 437 \& 439; Bosco, “Discretion and State Influence at the ICC”, supra note 248 , at 401. 
Preliminary examinations opened by the Prosecutor without article 12(3) declarations include many of the lengthiest preliminary examinations, such as those in Colombia, Afghanistan, Guinea, Georgia, Nigeria, and Honduras. Three notable exceptions to this trend include the preliminary examination in Kenya, which was concluded in less than two years, the preliminary examination in Burundi, which took just over one year and three months, and the preliminary examination in the DRC, which lasted only approximately two-and-a-half months. It is notable that all three of these involve African states.

In short, the average length of preliminary examinations ${ }^{268}$ based on the trigger has varied greatly, with only 33.5 days for Security Council resolutions, 510 days (just under a year and a half) for state party referrals, 1762 days (almost five years) for article 12(3) declarations, and 1666 days (just over four and a half years) for preliminary examinations opened proprio motu without an article 12(3) declaration.

As Pues notes, this discrepancy is probably due in part to the fact that the OTP is unlikely to require a lengthy complementarity assessment in situations involving referrals. ${ }^{269}$ State parties will presumably only make referrals if their own judiciary is incapable of prosecuting the relevant case(s) domestically. ${ }^{270}$ For example, in its referral to the Court "the Malian authorities informed the Office that $[\ldots]$ the Malian courts are unable to prosecute crimes". ${ }^{271}$ Similarly, after referring the situation on its territory to the ICC, the Democratic Republic of Congo confirmed that there was no national case underway against the Germain Katanga in relation to the Bogoro attack, because "at the time of the crimes (February 2003) [...] the DRC was unable genuinely to investigate the crimes' and 'since

\footnotetext{
268 Based on best available information including some approximations as described in the Research Method section above.

${ }^{269}$ Pues, supra note 10, at paras 440-1. See also Bosco, "Discretion and State Influence at the ICC", supra note 248, at 405.

270 One exception being Uganda. See Phil Clark, supra note 180, at 1202.

2712012 PE Report, supra note 56, at para. 182.
} 
then the situation has shown little improvement." ${ }^{272}$ Additionally, if the OTP receives a referral from either the Security Council or a state party (including a post hoc referral after the preliminary examination has been commenced), it does not need to prepare a submission requesting authorization of the investigation, which will shorten the preliminary examination considerably.

Preliminary examinations will also likely proceed more quickly with state cooperation, which will often (but not always) be present where the situation was referred to the ICC by a state with jurisdiction over the alleged crimes. ${ }^{273}$ This raises a question as to why the preliminary examinations opened by the Prosecutor upon receipt of an Article 12(3) declaration, which works like a self-referral from a state that is not (yet) a party to the Rome Statute, have all been relatively lengthy (the shortest being the Palestine I preliminary examination which took over three years). Furthermore, in some circumstances, preliminary examinations can be completed quickly even without cooperation from the relevant state. The OTP recently demonstrated this in relation to Burundi, in which a relatively swift preliminary examination resulted in a successful authorization to investigate, despite a lack of cooperation from the state and the inability of OTP staff to even enter the territory. ${ }^{274}$

At the end of the day, prioritization is inevitable due to limited resources of the Office. However, as commentators have rightly pointed out, the lack of transparency regarding how this prioritization is undertaken and the vastly differing timeframes among the preliminary examination inevitably creates room for critique. ${ }^{275}$ As Human Rights Watch has suggested, "when resource

\footnotetext{
272 ICC, Observations of the Democratic Republic of the Congo on the Challenge to Admissibility made by the Defence for Germain Katanga in the case of the Prosecutor versus Germain Katanga and Mathieu Ngudjolo Chui, Registry, 25 September 2009, ICC-01/04-01/071497, page 4.

273 Bosco, "Discretion and State Influence at the ICC", supra note 248, at 406-7.

${ }^{274}$ Burundi Request for Authorization, supra note 166, at para. 27; Aljazeera, "UN commission: Burundi commits crimes against humanity”, 4 September 2017, available online: <https://www.aljazeera.com/news/2017/09/commissionburundi-commits-crimes-humanity-170904133352582.html $>$ (accessed 19 August 2018).

275 Pues, supra note 10 at 436; Grotius Centre Report, supra note 6, at para. 32.
} 
constraints factor into decisions about situations under analysis, the OTP should openly acknowledge that fact, lending increased transparency and credibility to OTP decision-making." 276

\section{Preliminary Examinations and Prosecutors}

As of 30 November 2018, Prosecutor Bensouda had only completed approximately 6.5 years (just over $72 \%$ ) of her 9-year term. Even so, some initial comparison of the OTP's preliminary examinations under the leadership of its two prosecutors is possible. During his nine-year term, Luis Moreno-Ocampo opened 17 preliminary examinations, ten of which (59\%) were concluded by the end of his term. Of these ten, seven resulted in the opening of an investigation and three were closed with a decision not to proceed to an investigation (Venezuela I, Palestine I, and Iraq/UK).

Of the seven preliminary examinations that were opened by Moreno-Ocampo but not concluded as of the end of his term, three still remain continuously ongoing. These include the preliminary examinations in Colombia, Guinea, and Nigeria, which are among the longest running preliminary examinations to date. The Iraq/UK preliminary examination, which Bensouda "reopened" in 2014, also remains ongoing. Two preliminary examinations opened by Moreno-Ocampo were later closed by Bensouda, namely Honduras and South Korea. Two other preliminary examinations opened by Moreno-Ocampo concluded with a decision by Bensouda to proceed to an investigation (Georgia and Afghanistan). It is also noteworthy that all of the preliminary examinations inherited by Bensouda from Moreno-Ocampo's tenure were opened proprio motu on the basis of article 15 communications, whereas Moreno-Ocampo completed all preliminary examinations opened by state party referral, Security Council referral, and article 12(3) declaration before leaving office.

${ }^{276}$ Human Rights Watch, 'ICC: Course Correction', supra note 222. 
In total, by the end of Moreno-Ocampo's term, seven ${ }^{277}$ out of seventeen PEs resulted in a decision to proceed to an investigation, three ${ }^{278}$ were closed with a decision not to proceed to an investigation (although one of these, namely Iraq/UK, was subsequently "re-opened"), and another seven $^{279}$ remained underway").

The Court's second prosecutor, Fatou Bensouda, took office on 15 June 2012. During her term, the OTP has opened ten new preliminary examinations, ${ }^{280}$ "re-opened" the Iraq/UK preliminary examination, and continued work on the seven preliminary examinations inherited from MorenoOcampo. This brings the number of preliminary examinations worked on during Bensouda's term to date to eighteen which has already surpassed the total number during her predecessor's term. In relation to outcomes of preliminary examinations during Bensouda's term, as of 30 November 2018, four have led to investigations, ${ }^{281}$ a fifth (Afghanistan) will potentially proceed to investigation pending the Pre-Trial Chamber's decision, four have been closed without an investigation, ${ }^{282}$ and nine are ongoing. ${ }^{283}$ That breakdown may change by the end of Prosecutor Bensouda's term, which will end in June 2021.

\section{CONCLUSION}

This comprehensive analysis of the OTP's preliminary examinations adds a much needed "birds-eye view" to the rapidly growing scholarship on this important area of the ICC's work. It gives a sense of

\footnotetext{
277 Namely: CAR I, Côte d'Ivoire, Darfur, DRC, Kenya, Libya, and Uganda.

${ }^{278}$ Namely: Iraq/UK, Palestine I, and Venezuela I.

279 Namely: Afghanistan, Colombia, Georgia, Guinea, Honduras, Nigeria, and South Korea.

280 Namely: Bangladesh/Myanmar, Burundi, CAR II, Comoros, Gabon, Mali, Palestine II, the Philippines, Ukraine, Venezuela II.

281 Namely: Burundi, CAR II, Georgia, and Mali.

282 Namely: Comoros, Gabon, Honduras, and South Korea.

${ }^{283}$ Namely: Bangladesh/Myanmar, Colombia, Guinea, Iraq/UK, Nigeria, Palestine II, the Philippines, Ukraine, and Venezuela II.
} 
the major energy expended by the OTP at this very early stage of proceedings, enables a more informed assessment of where the ICC has been most active and why, and gives an indication of where the Court's work may be heading in the future.

The paper has also identified a number of points on which further research is warranted that are beyond the scope of this analysis, in particular in relation to many substantive points of law. As shown above, the OTP's analysis at the preliminary examinations stage spans a wide range of legal issues, and functions almost as a mini-jurisprudence in its own right. For example, the statute's gravity threshold has been considered in detail by the OTP and Pre-Trial Chamber in the Comoros preliminary examination. Similarly, a look at the Honduras, Venezuela I, and Gabon preliminary examinations may shed light on the OTP's analysis of the application of the contextual elements of crimes against humanity and the South Korea preliminary examination contains the OTP's first interpretation of the war crime of "perfidy" (i.e. killing or wounding treacherously), which is currently also being considered in the preliminary examination in Ukraine. As well, the South Korea preliminary examination contains a critical jurisdictional determination by the OTP which it referenced in its recent application seeking a jurisdictional ruling in relation to allegations of deportation of Rohingya people from Myanmar to Bangladesh that has recently garnered significant attention. ${ }^{284}$

Ongoing preliminary examinations also give considerable insight into the OTP's "positive complementarity" efforts, and may shed light on the largely unexamined concept of the "interests of justice". It is also worth keeping an eye on current preliminary examinations where the Prosecutor is examining crimes not previously given consideration before the Court such as allegations of genderbased persecution in both the Afghanistan and Nigeria preliminary examinations. The importance of these issues suggest that this largely over-looked body of analysis deserves closer attention. Finally, it

\footnotetext{
${ }^{284}$ ICC-OTP, Application under Regulation 46(3), "Prosecution's Request for a Ruling on Jurisdiction under Article 19(3) of
} the Statute", 9 April 2018, ICC-RoC46(3)-01/18-1 at para. 14. 
is also hoped that this work will provide fruit for further reflection, debate, and comparison as the OTP's work progresses and as new prosecutors take the helm. 